\title{
Quality of Water in the Fractured- Bedrock Aquifer of New Hampshire
}

By Richard Bridge Moore

In cooperation with the New Hampshire Department of Environmental Services

Scientific Investigations Report 2004-5093

U.S. Department of the Interior

U.S. Geological Survey 


\title{
U.S. Department of the Interior \\ Gale A. Norton, Secretary \\ U.S. Geological Survey \\ Charles G. Groat, Director
}

\section{U.S. Geological Survey, Reston, Virginia 2004}

\author{
For sale by U.S. Geological Survey, Information Services \\ Box 25286, Denver Federal Center \\ Denver, CO 80225 \\ For more information about the USGS and its products: \\ Telephone: 1-888-ASK-USGS \\ World Wide Web: http://www.usgs.gov/
}

\begin{abstract}
Any use of trade, product, or firm names in this publication is for descriptive purposes only and does not imply endorsement by the U.S. Government.

Although this report is in the public domain, permission must be secured from the individual copyright owners to reproduce any copyrighted materials contained within this report.
\end{abstract}

Suggested Citation:

Moore, R.B., 2004, Quality of water in the fractured-bedrock aquifer of New Hampshire: U.S. Geological Survey Scientific Investigations Report 2004-5093, 30 p. 


\section{Contents}

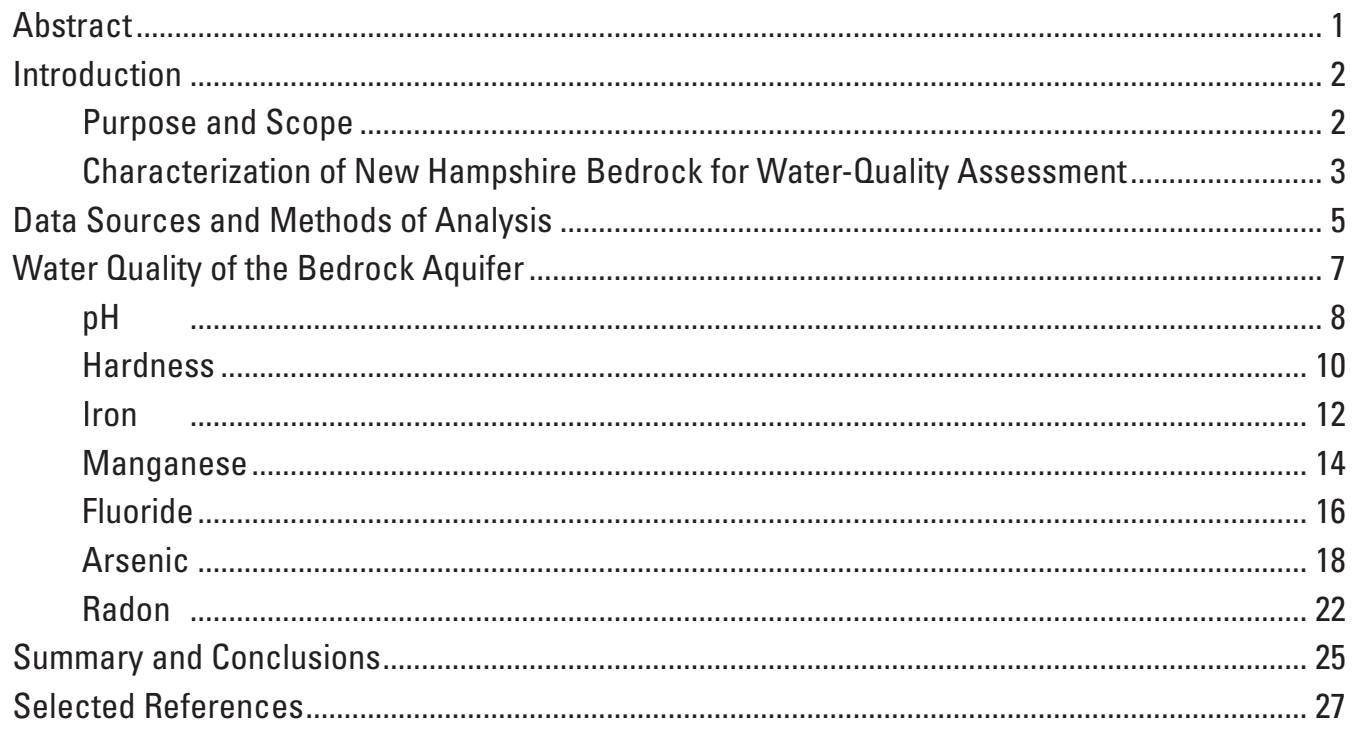

\section{Figures}

\section{1-10 Maps showing}

1. Areal distribution of major lithochemical groups in New Hampshire used for statistical analyses.

2. Areal distribution of radon-potential categories in New Hampshire used for statistical analyses.

3. Location of domestic-bedrock-well sample sites in New Hampshire and statistical distribution of water-quality data in relation to lithochemical groups for $\mathrm{pH}$.

4. Location of domestic-bedrock-well sample sites in New Hampshire for total hardness concentration and statistical distribution of concentrations in relation to lithochemical groups.

5. Location of domestic-bedrock-well sample sites in New Hampshire for total iron concentration and statistical distribution of concentrations in relation to lithochemical groups.

6. Location of domestic-bedrock-well sample sites in New Hampshire for total manganese concentration and statistical distribution of manganese concentrations in relation to lithochemical groups.

7. Location of Crawford Notch with reported large crystals of fluorite and towns in New Hampshire with reported noteworthy locations with arsenopyrite, shown in relation to lithochemical groups. 
8. Location of domestic-bedrock-well sample sites in New Hampshire for total fluoride concentration and statistical distribution of concentrations in relation to lithochemical groups.

9. Location of domestic-bedrock-well sample sites in New Hampshire for total arsenic concentration and statistical distribution of concentrations in relation to lithochemical groups.

10. Location of public-supply bedrock-well sample sites in New Hampshire for total arsenic concentration and statistical distribution of concentrations in relation to lithochemical groups.

11. Graph showing statistical distribution of radon in air concentrations from single family homes with drilled wells in New Hampshire in relation to radon-potential categories.

12-13. Maps showing:

12. Location of domestic-bedrock-well sample sites in New Hampshire for radon concentration in ground water and statistical distribution of concentrations in relation to radon-potential categories.

13. Location of public-supply bedrock-well sample sites in New Hampshire for radon concentration in ground water and statistical distribution of concentrations in relation to radon-potential categories.

\section{Conversion Factor}

\begin{tabular}{lcl}
\hline Multiply & By & To obtain \\
\hline & Volume & \\
milligram per liter $(\mathrm{mg} / \mathrm{L})$ & 1,000 & microgram per liter $(\mu \mathrm{g} / \mathrm{L})$ \\
\hline
\end{tabular}

\section{Water-Quality Constituents and Acronyms}

Concentrations of chemical constituents in water are given either in milligrams per liter $(\mathrm{mg} / \mathrm{L})$, micrograms per liter $(\mu \mathrm{g} / \mathrm{L})$., or picoCurie per liter ( $\mathrm{pCi} / \mathrm{L})$. Arsenic concentrations in rock are measured in milligrams per kilogram $(\mathrm{mg} / \mathrm{kg})$.

\section{Acronyms Used in This Report}

$\begin{array}{ll}\text { MCL } & \text { Maximum Contaminant Level } \\ \text { NHGS } & \text { New Hampshire Geological Survey } \\ \text { SMCL } & \text { Secondary Maximum Contaminant Level } \\ \text { USEPA } & \text { U.S. Environmental Protection Agency } \\ \text { USGS } & \text { U.S. Geological Survey }\end{array}$




\section{ACKNOWLEDGMENTS}

Special thanks are extended to the New Hampshire Department of Environmental Services (NHDES) for providing much of the water-quality and well-construction data used in this report. The project would not be possible without the wealth of well data recorded by the well drillers and reported to the New Hampshire Water Well Board. These data were compiled and computerized and the geographic coordinates of the well locations determined by NHDES. The author thanks Frederick Chormann, of the New Hampshire Geological Survey (NHGS), NHDES, for providing cross-referencing between the well and water-quality databases; Eugene Boudette, former New Hampshire State Geologist, and Stewart Clark, Jr., U.S. Geological Survey (USGS), for providing preliminary bedrock groupings for radon potential; David Chase, New Hampshire Department of Health and Human Services, Radon Program, for providing radon-in-air data relative to these groupings; Joseph Ayotte, USGS, for providing the waterquality data for public-supply wells; and to John Peper, USGS, for extending his categorization of lithochemical groups for the Connecticut River Basin to cover all of New Hampshire for this study. 



\title{
Quality of Water in the Fractured-Bedrock Aquifer of New Hampshire
}

\author{
By Richard Bridge Moore
}

\begin{abstract}
Over the past few decades, New Hampshire has experienced considerable population growth, which is forcing some communities to look for alternative public and private water supplies in the bedrock aquifer. Because the quality of water from the aquifer can vary, the U.S. Geological Survey statistically analyzed well data from 1,353 domestic and 360 publicsupply bedrock wells to characterize the ground water. The domestic-well data were from homeowner-collected samples analyzed by the New Hampshire Department of Environmental Services (NHDES) Environmental Laboratory from 1984 to 1994. Bedrock water in New Hampshire often contains high concentrations of iron, manganese, arsenic, and radon gas. Water samples from 21 percent of the domestic bedrock wells contained arsenic above the U.S. Environmental Protection Agency (USEPA) 10 micrograms per liter $(\mu \mathrm{g} / \mathrm{L})$ drinkingwater standard for public-water supplies, and 96 percent had radon concentrations greater than the USEPA-proposed 300 picocurie per liter (pCi/L) standard for public-water supplies. Some elevated fluoride concentrations (2 percent of samples) were above the 4 milligrams per liter ( $\mathrm{mg} / \mathrm{L}$ ) USEPA drinking-water standard for public-water supplies. Water from the bedrock aquifer also typically is soft to moderately hard, and has a $\mathrm{pH}$ greater than 7.0.

Variations in bedrock water quality were discernable when the data were compared to lithochemical groupings
\end{abstract}

of the bedrock, indicating that the type of bedrock has an effect on the quality of water in the bedrock aquifer of New Hampshire. Ground-water samples from the metasedimentary lithochemical group have greater concentrations of total iron and total manganese than do the felsic and mafic igneous lithochemical groups. Ground-water samples from the felsic igneous group have higher concentrations of total fluoride than do those from the other lithochemical groups. For arsenic, the calcareous metasedimentary group was identified, using the public-supply database, as having higher concentrations, on average, than the other lithochemical groups. The use of a radon-gas-potential classification of bedrock in the State indicated where high radon concentrations in the air and in water from private and public-supply wells were more likely to occur.

In general, samples from the bedrock aquifer tend to have higher $\mathrm{pH}$ (are less acidic), greater hardness, much higher concentrations of iron, similar concentrations of manganese, and higher concentrations of fluoride and arsenic than do samples from stratified-drift aquifers in New Hampshire. An understanding of the water-quality conditions of water in bedrock aquifers is important from a public-health perspective because an increasing number of domestic bedrock wells are being drilled and relied upon as a source of drinking water in the State. 


\section{Introduction}

New Hampshire has experienced considerable population growth over the past few decades (New Hampshire State Data Center, 2001), which has led many communities to search for new drinking-water supplies. Many of these communities experiencing population growth have limited stratified-drift (sand and gravel) aquifers that historically have been the most favorable aquifers for constructing municipal wells. As a result, communities are increasingly looking to the fractured crystalline bedrock aquifer for additional water supplies. Also, much of this new population, and accompanying development, is relying on the use of domestic wells that are drilled into the crystalline bedrock aquifer. Understanding the variability of water quality within the fractured crystalline bedrock aquifer (termed the bedrock aquifer throughout this report) may be an important consideration when evaluating this resource as a future drinking-water supply.

Ground-water chemistry in the fractured-bedrock aquifer is dependent on various hydrogeologic factors such as mineral composition, physical contact, residence time, and oxidation-reduction conditions; all factors that affect the solubility of bedrock minerals. Increased residence time and physical contact between the bedrock and the ground water increases the potential for the water to react with the rock, typically resulting in more dissolution of minerals. Fractures increase surface area, which in turn provides for a greater potential for the water to react with the bedrock. Residence time and oxidation-reduction conditions, which control mineral solubility, are affected by the amount of water moving through the groundwater system, and by recharge, discharge, and flow rates. Certain minerals dissolve much more readily if the oxygen has been depleted along the ground-water-flow path.

The quality of ground water from stratified-drift and bedrock aquifers in New Hampshire has been studied by numerous previous investigations. These studies include Morrissey and Regan (1988), Rogers (1989), Medalie and Moore (1995), and Ayotte and others (1999). Morrissey and Regan (1988) provide a generalized description of water quality in the bedrock and stratified-drift aquifers, and discussed the effects of land use on ground-water quality. Rogers (1989) provided a geochemical comparison of ground water in bedrock and stratified-drift aquifers in areas in New England, New York, and Pennsylvania. Medalie and Moore (1995) summarize water-quality data and conditions of stratified-drift aquifers throughout New Hampshire.

A number of recent studies have focused on the occurrence of arsenic and other metals in bedrock water for parts of New Hampshire. Ayotte and others (1999) used available data from a selected set of public-supply wells drilled in bedrock to determine the relation of arsenic, iron, and manganese in ground water to aquifer type, bedrock lithogeochemistry, and land use in parts of Eastern New England, including eastern New Hampshire. Ayotte and others (2003) described arsenic concentrations in ground water and factors that may be controlling arsenic in Eastern New England based on newly collected water-quality data from a variety of wells. Montgomery and others (2003) present the results of a study of arsenic in water samples from domestic bedrock wells in Stratford, Rockingham, and Hillsborough Counties of southeastern New Hampshire.

The New Hampshire Department of Environmental Services (NHDES) Environmental Laboratory (Laboratory) has been analyzing water samples from private domestic and public-water supply wells throughout the State when requested by the well owner. These analyses may be helpful for describing ground-water quality; however, there were no comprehensive assessments of the water-quality data from the Laboratory available before this study. The U.S. Geological Survey (USGS), in cooperation with the NHDES, assessed the variability of a number of water-quality measurements and constituents in domestic and public bedrock wells throughout the State using the well data from the NHDES Laboratory and other available data sets. This assessment is part of the New Hampshire Bedrock Aquifer Assessment Project, which is intended to provide information that can be used by communities, industry, professional consultants, and other interests to evaluate the potential for ground-water development of the bedrock aquifer. This report on the water quality of the bedrock aquifer is one of three companion reports that present the results of the USGS New Hampshire Bedrock Aquifer Assessment Project. The other two reports cover the topics of well yields, evaluated at a statewide and regional scale (Moore and others, 2002), and geophysical investigations at well fields (Degnan and others, 2001). These two reports were designed to identify relations that have the potential to increase the probability of successfully locating high-yield water supplies in the bedrock aquifer underlying New Hampshire.

\section{Purpose and Scope}

This report describes and summarizes bedrock groundwater-quality data that were available from the NHDES Environmental Laboratory from 1984 to 1994 . Water-quality measurements and constituent data that were evaluated include $\mathrm{pH}$, hardness, iron, manganese, fluoride, arsenic, and radon. These measurements and constituents are those most routinely analyzed by the Laboratory. Statistical analyses are used to quantify data variability, and to identify differences between groupings of mapped bedrock units. Comparisons are made to primary and secondary Federal and State drinking-water standards and to the water-quality conditions of the stratified-drift aquifers above the bedrock in some locations. 


\section{Characterization of New Hampshire Bedrock for Water-Quality Assessment}

Bedrock units in New Hampshire have been characterized as to their potential effect on the chemical composition of ground water (Robinson, 1997, Montgomery and others, 2002) and classified into lithochemical groups. These characterizations are based on mineralogical and chemical characteristics relevant to water quality, which include the reactivity of constituent minerals to dissolution and the presence of carbonate or sulfide minerals (John D. Peper, U.S. Geological Survey, written commun., 1994 and 1996; Robinson and others, 2002; Montgomery and others, 2002). Carbonate and sulfide miner- als are important to water quality because these are highly reactive minerals in solution. All 174 mapped bedrock units on the Bedrock Geologic Map of New Hampshire (Lyons and others, 1997) have been assigned to 4 major lithochemical groups. Major groups found in New Hampshire (fig. 1) are: (1) calcareous metasedimentary rocks; (2) primarily noncalcareous, clastic metasedimentary rocks at or above biotite-grade of regional metamorphism; (3) mafic igneous rocks and their metamorphic equivalents; and (4) felsic igneous rocks and their metamorphic equivalents. Nine percent of the State is underlain by calcareous metasedimentary rocks, 34 percent

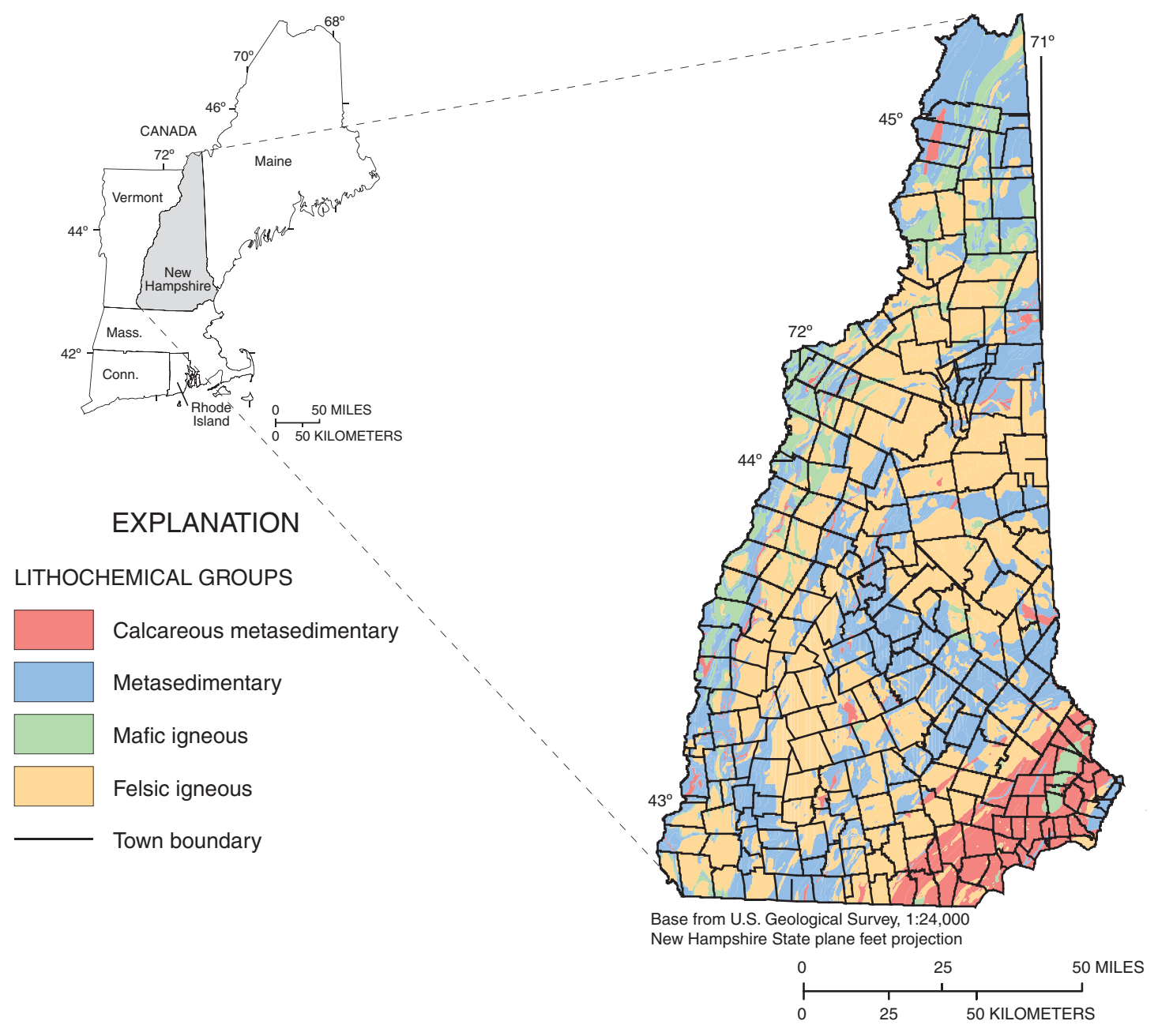

Figure 1. Areal distribution of major lithochemical groups in New Hampshire used for statistical analyses. Mapped bedrock units (Lyons and others, 1997) were grouped into lithologic categories on the basis of mineralogical and chemical characteristics relevant to water quality. 
by noncalcareous metasedimentary rocks, 9 percent by mafic igneous rocks, and 48 percent by felsic igneous rocks.

Mapped bedrock units of New Hampshire have also been grouped for relative potential of producing radon gas (Eugene Boudette, New Hampshire State Geologist, written commun., to David Chase, New Hampshire Department of Health and Human Services, Radon Program, 1999; Stewart F. Clark, Jr., U.S. Geological Survey, written commun., 2000). Three broad categories of radon potential-high, medium, and low-were defined on the basis of lithology and mineralogy (fig. 2). New
Hampshire is underlain mainly by granitic and metamorphic rocks, many of which have a high potential for containing uranium and its daughter products including radon (Boudette, 1994). Two-mica granites and associated pegmatites are identified especially with high levels (greater than 4,000 pCi) of radon (Boudette, 1977). Twenty-two percent of the State is underlain by the rocks in the high radon-potential category, 58 percent in the medium radon-potential category, and 20 percent in the low radon-potential category.

\section{EXPLANATION}

RADON-POTENTIAL CATEGORIES

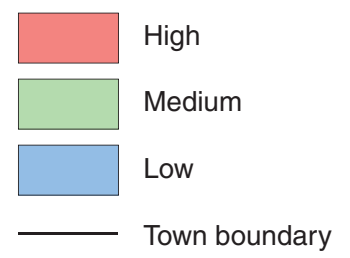

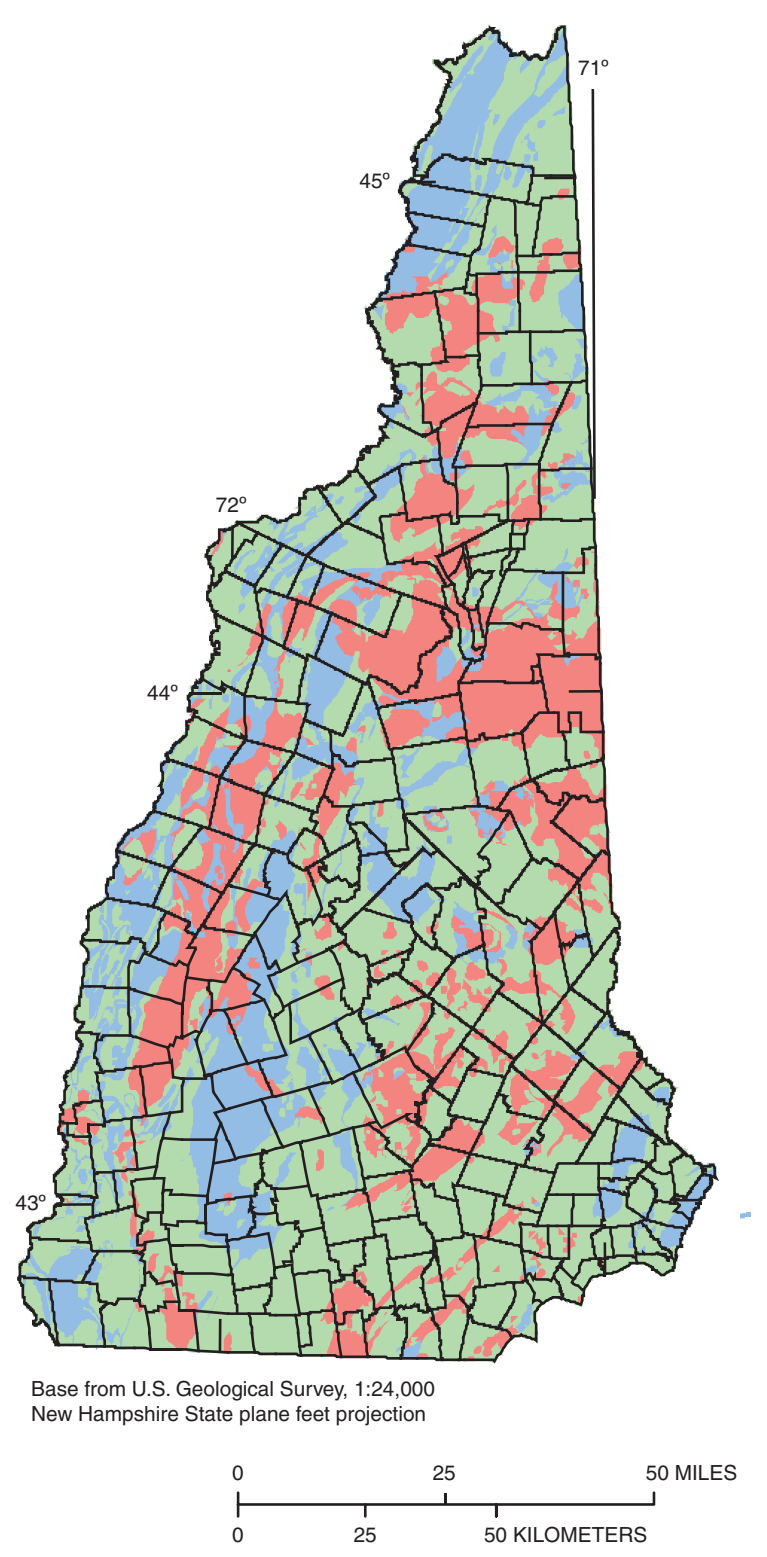

Figure 2. Areal distribution of radon-potential categories in New Hampshire used for statistical analyses. Mapped bedrock units (Lyons and others, 1997) were grouped for relative potential of producing radon gas. 


\section{Data Sources and Methods of Analysis}

Water-quality data maintained by the NHDES Laboratory served as the primary source of data used in the analysis. This database consisted of 1,818 sample analyses from 1,353 domestic wells collected during 1984-94 throughout New Hampshire. Samples were collected and submitted to the NHDES Laboratory by homeowners or residents. Water-quality measurements and constituents provided in the database included $\mathrm{pH}$, hardness, iron, manganese, fluoride, radon, and arsenic. In addition to water-quality data, radon air-concentration data were obtained from the New Hampshire Department of Health and Human Services, Radon Program, (David Chase, written commun., 1999) to assist in the characterization of radon variability in bedrock aquifers.

The water-quality data maintained by the NHDES Laboratory did not contain information on the location of the well. To identify a well's location, data describing the owner and address in the water-quality database were matched with similar data in a well-construction database maintained by the NHGS. This well-construction database contains information on the depth of the well, construction characteristics, geologic material encountered during drilling, and the geographic coordinates for over 21,000 bedrock wells in New Hampshire.

Most (68 percent) of the water-quality samples analyzed by the Laboratory were obtained within 2 years of well construction on the basis of a comparison of dates in the two databases. Therefore, the evaluation of a new water source appears to be the primary reason for the homeowners sampling their well water.

Analyses of arsenic and radon in water of public-supply bedrock wells were used in addition to the arsenic and radon data in the Laboratory database. The data for public-water supplies are the result of public-water-supply monitoring to determine compliance with Federal Safe Drinking Water Act requirements and are the same data used by Ayotte and others (1999). These data represent water suppliers that (a) had one supply source (a single well), and (b) were not required to do any treatment (Ayotte and others, 1999).

Applying these water-quality data to characterizations of the bedrock aquifer statewide required a number of assumptions. First, it was assumed that differences in laboratory analytical techniques produced results that were, for each constituent, directly comparable; thus, allowing the aggregation of the data into a single database. All analyses were done by a single U.S. Environmental Protection Agency (USEPA) certified laboratory that follows standard analytical procedures. To account for changing detection levels, all less-than values were set to the highest less-than value for each specific constituent. Second, it is assumed that sample-collection procedures by the homeowner or water supplier had no or minimal affect on sample results. Third, if a well had multiple values for the same measurement type or constituent analyzed, only the highest value was kept in the database. This highest value was assumed to be the best indicator of untreated well water; thus minimizing the incorporation of treated water samples. Treated water may not be reflective of the quality of water as it leaves the ground.

A number of statewide analyses were performed with the water-quality data. To allow for comparisons of water-quality conditions among the four major lithochemical groups, all bedrock wells with water-quality data other than radon concentrations were assigned to one of the four major lithochemical groups. This relation was accomplished with a geographic information system using the location of the well. Likewise, wells with radon data were assigned to one of the three radon-potential categories. The water-quality data, by measurement/constituent, were summarized statistically for each lithochemical group and radon-potential category and graphically displayed with cumulative-frequency distribution plots to display differences in the data sets. The cumulative-frequency distribution plots display the data ranked from lowest to highest. Measurements or concentrations of constituents are plotted on the $\mathrm{x}$-axis and the cumulative frequency on the $\mathrm{y}$ axis. Concentrations below the detection limit are assigned the same low rank and are not plotted individually. The cumulative frequency is essentially the inverse of the probability. For example, concentrations with a cumulative frequency of 0.1 are equaled or exceeded in 90 percent of the sample population and concentrations or values with a cumulative frequency of 0.5 are the median value.

After the analyses described above were completed, nonparametric tests then were used to define significant statistical differences between data associated with the lithochemical groups and radon-potential categories. A Kruskal-Wallis test (Helsel and Hirsch, 1992; SAS Institute, Inc., 1999) was used to test the null hypothesis that the water-quality data falling in the four major lithochemical groups (or three estimated radon-potential categories) are from the same population. The null hypothesis indicates that there is no significant difference among the means of the ranks of the concentrations of a chemical constituent between the groups. To detect specific significant differences between populations in pairs of lithochemical groups, a subsequent multiple-stage Kruskal-Wallis test was used. This multiple-stage test is valid only if the null hypothesis was rejected in the initial Kruskal-Wallis test (Helsel and Hirsch, 1992, SAS Institute, Inc., 1999). For all possible pair-wise comparisons (comparing two groups, one to another), a within-group variance is used in the multiplestage test to calculate the minimum difference in mean rank that is necessary to consider groups significantly different (SAS Institute, Inc., 1999). For all statistical tests described in this report, rejection of the null hypothesis required that the attained significance level (p) be less than 0.05 .

Statewide and lithochemical-group and radon-potentialcategory summary statistics were compared to appropriate USEPA drinking-water standards that apply to public-water supplies (U.S. Environmental Protection Agency, 2002a and b). Water-quality data from each measurement type or constituent were compared to the Maximum Contaminant Levels (MCL), which are enforceable USEPA primary drinking-water 
standards, or to Secondary Maximum Contaminant Levels (SMCL), which are USEPA-recommended health advisory levels for certain contaminants in public-water supplies (U.S. Environmental Protection Agency, 2002a and b). There are no enforceable statewide drinking-water standards for water from private domestic wells. Lastly, statewide median values for the bedrock aquifer were compared to the statewide median value of water from stratified-drift aquifers throughout New Hampshire as reported by Medalie and Moore (1995). 


\section{Water Quality of the Bedrock Aquifer}

Water-quality samples from a total of 1,713 wells from throughout New Hampshire were used to characterize water from the bedrock aquifer in the State. Although most wells are for private domestic use, 357 public-supply bedrock wells had arsenic data and 310 public-supply bedrock wells had radon data (Joseph Ayotte, U.S. Geological Survey, written commun., 1999). The total domestic-well database includes 1,078 wells with $\mathrm{pH}$ data, 1,076 wells with hardness, 1,078 with total iron, 1,076 with total manganese, 1,138 with total fluoride, 191 with total arsenic, and 221 wells with radon concentrations.

Most ground water from bedrock wells in New Hampshire is suitable for drinking. However, arsenic and radon concentrations frequently are greater than MCLs in some areas of the State, whereas fluoride concentrations occasionally exceed the MCL. Iron and manganese also are common nuisance contaminants but these do not pose a threat to human health. The following sections contain a description and statistical analysis on the occurrence of $\mathrm{pH}$, hardness, iron, manganese, fluoride, arsenic, and radon in bedrock ground water.

Two potential biases, spatial and self-selection biases, may be present in the data analyzed in this report. The first potential spatial bias may result because of a greater frequency of sample collection in central New Hampshire than other parts of the State because people who live in this area are near the NHDES Laboratory (see figs. 3-9). As a result, the data used in these analyses could underrepresent wells that are remote from the NHDES Laboratory. For this reason, welllocation plots are provided with a discussion for each chemical constituent to show where the samples were collected.

The second potential bias is that of sample self selection. Well owners may submit samples because they are experiencing a water-quality problem or suspect that they may have a problem. This particular situation is true of the arsenic and radon analyses, and to a lesser extent iron and manganese (Frederick Chormann, New Hampshire Department of Environmental Services, written commun., 2003). Peters and others (1999) evaluated this bias for an arsenic data set from New Hampshire and found that this bias is likely to increase the median value of arsenic, but it did not affect which areas or bedrock types had the highest concentrations. Self-selection bias is, therefore, unlikely to affect the comparisons presented in this report between samples from different lithochemical groups. Furthermore, it is possible that the self-selection bias is minimized in the data described in this report because the evaluation of a new water source appears to be the prime motivation for sampling the wells in the database. 


\section{pH}

The $\mathrm{pH}$ of water is a measure of the hydrogen-ion activity. The $\mathrm{pH}$ scale ranges from 0 to 14 where each unit increase in the scale represents a tenfold decrease in hydrogen-ion activity. Water with a pH of 7.0 is neutral, less than 7.0 is acidic, and greater than 7.0 is alkaline. A recommended SMCL range of $\mathrm{pH}$ for public-water supplies is 6.5 to 8.5 (U.S. Environmental Protection Agency, 2002b). At low pH, below 6.5, metal pipes can corrode introducing metallic contaminants and a bitter metallic taste to the water. At high $\mathrm{pH}$, greater than 8.5, the water is apt to be hard imparting a slippery feel and soda taste, and create mineral deposits (U.S. Environmental Protection Agency, 2002b).

The bedrock aquifer of New Hampshire is typically alkaline, having a median $\mathrm{pH}$ of 7.7. Twenty-one percent of the $\mathrm{pH}$ data were less than 7.0 indicating slightly acidic conditions for water from these wells. Ten percent of the water samples had a $\mathrm{pH}$ less than 6.5 , and 2 percent had a $\mathrm{pH}$ greater than 8.5 meaning that water from about 12 percent of the bedrock wells in the State may require treatment to adjust $\mathrm{pH}$.

Statistically significant differences in $\mathrm{pH}$ values among lithochemical groups are evident (fig. 3). Ground-water sam- ples from the mafic igneous group have higher $\mathrm{pH}$ values than do those either from the felsic igneous group or the metasedimentary group, whereas the $\mathrm{pH}$ for samples from calcareous metasedimentary do not differ significantly from any of the other groups (fig. 3).

The mafic igneous group had the lowest percentage of ground-water samples outside the range of the USEPA SMCL drinking-water standard for $\mathrm{pH}$ (6.5 to 8.5). Only 4 percent of the water samples from the mafic igneous group had $\mathrm{pH}$ below 6.5; compared to 10 to 12 percent of the water samples from the other lithochemical groups. The mafic igneous group also had the lowest percentage ( 1 percent) of $\mathrm{pH}$ values above 8.5; 2 and 3 percent of the samples from the metasedimentary and felsic igneous groups, respectively; and 7 percent from the calcareous metasedimentary were above 8.5 .

Water from the bedrock aquifer typically has higher $\mathrm{pH}$ (is less acidic, more basic) than does water from stratified-drift aquifers locally above the bedrock. The median $\mathrm{pH}$ of water from stratified-drift aquifers in New Hampshire is 6.3 (Medalie and Moore, 1995) as compared to a median $\mathrm{pH}$ of 7.7 for water from the bedrock aquifer. Water in the stratified-drift aquifer is usually more reflective of water newly introduced to the ground-water system and, therefore, often is similar in quality to rainwater and is less chemically evolved than bedrock water. 
Cumulative frequency plot of $\mathrm{pH}$ by lithochemical group. Gray area is

U.S. Environmental Protection Agency recommended range of $\mathrm{pH}(6.5$ to 8.5$)$.

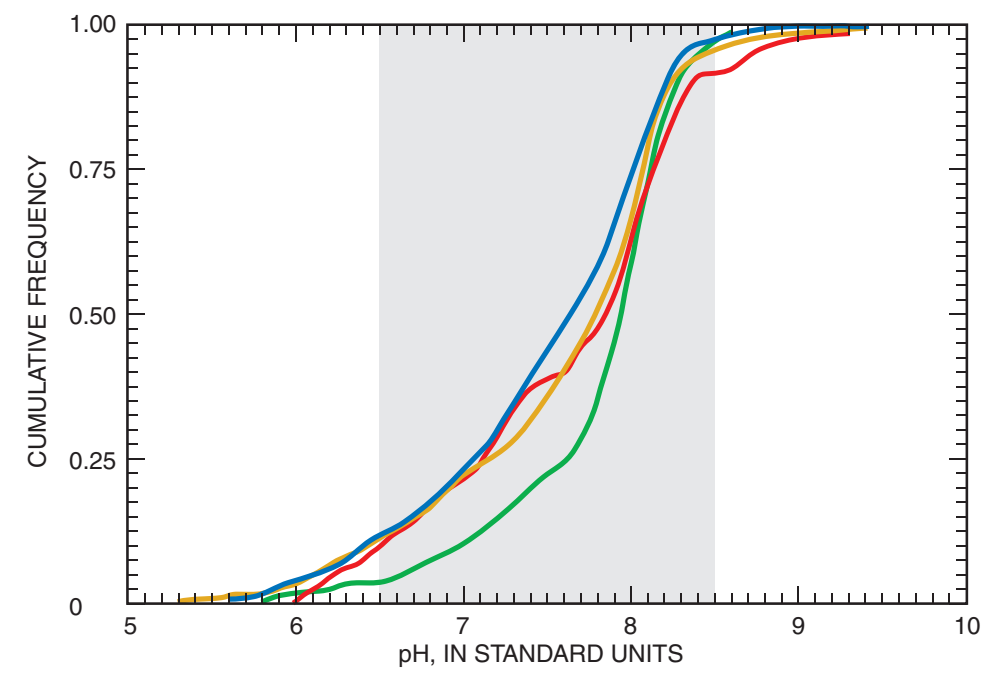

pH

\section{(Domestic wells)}

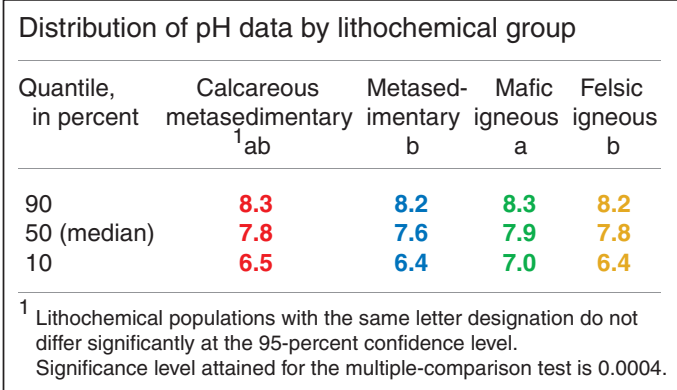

\section{EXPLANATION}

\section{LITHOCHEMICAL GROUPS}

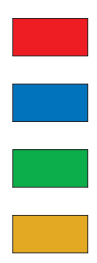

Calcareous metasedimentary [68]

Metasedimentary [417]

Mafic igneous [95]

Felsic igneous [498]

[68] Number of samples

- Domestic well sampled for $\mathrm{pH}$

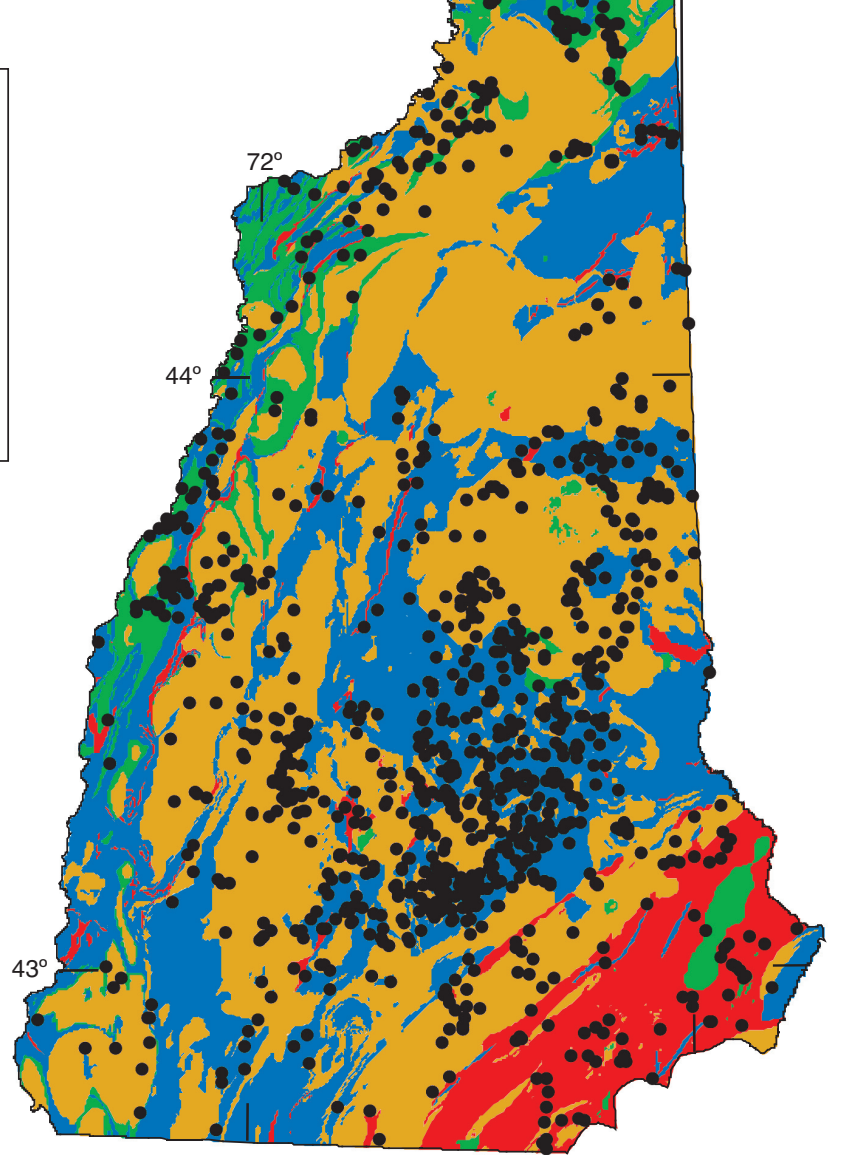

New Hampshire State plane feet projection

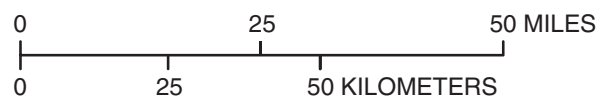

Figure 3. Location of domestic-bedrock-well sample sites in New Hampshire and statistical distribution of water-quality data in relation to lithochemical groups for $\mathrm{pH}$. 


\section{Hardness}

Hardness of water is a property or characteristic not attributable to a single constituent or mineral and usually is expressed in terms of an equivalent concentration of calcium carbonate $\left(\mathrm{CaCO}_{3}\right.$. Hardness typically is calculated from calcium and magnesium concentrations) (Hem, 1985). Although a variety of categorization schemes are used in the water industry. Durfor and Becker (1964) define $60 \mathrm{mg} / \mathrm{L} \mathrm{CaCO}_{3}$ or less as soft; 61 to $120 \mathrm{mg} / \mathrm{L} \mathrm{CaCO}_{3}$ as moderately hard; 121 to $180 \mathrm{mg} / \mathrm{L}$ as hard, and greater than $180 \mathrm{mg} / \mathrm{L} \mathrm{CaCO}_{3}$ as very hard (fig. 4). Hardness in drinking water is not known to pose a health risk. Rather, hard water creates other problems such as soap scum (most noticeable on tubs and showers), white mineral deposits on dishes and plumbing fixtures, and reduced efficiency of water heaters. USEPA has not established a MCL or a SMCL for hardness.

Ground water from the bedrock aquifer in New Hampshire typically is soft to moderately hard (fig. 4), having a median hardness value of $65 \mathrm{mg} / \mathrm{L}$. Of the 1,076 samples analyzed for hardness, 45 percent of the water is soft, 44 percent is moderately hard, 7 percent is hard and 4 percent is very hard.

Hardness values are significantly different among lithochemical groups. Samples from the mafic igneous group indicate harder water than the metasedimentary and felsic igneous groups (fig. 4). Samples from the calcareous metasedimentary group were harder than samples from the metasedimentary group.

Water in the calcareous metasedimentary and mafic igneous groups were classified as hard or very hard water for 22 and 16 percent of the samples, respectively; this result compares to less than 12 percent of the water samples from the other two lithochemical groups. Conversely, 47 and 48 percent of the samples from the felsic igneous and metasedimentary groups, respectively, are considered soft. Only 25 percent of the samples from the mafic group are soft (fig. 4).

Water from the bedrock aquifer typically has greater hardness than does water from stratified-drift aquifers. The median hardness of water from stratified-drift aquifers in New Hampshire is $22 \mathrm{mg} / \mathrm{L} \mathrm{CaCO}_{3}$ (Medalie and Moore, 1995). This value compares to a median hardness of $65 \mathrm{mg} / \mathrm{L} \mathrm{CaCO}_{3}$ for water from the bedrock aquifer. 
Cumulative frequency plot of hardness concentrations by lithochemical group.

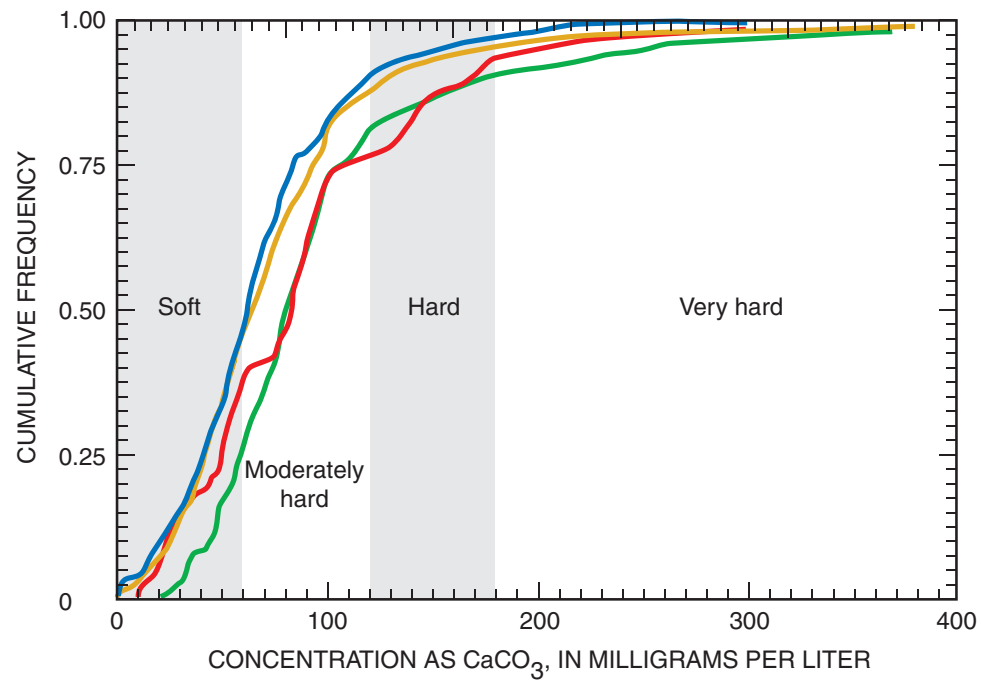

Hardness

(Domestic wells)

Distribution of hardness concentrations by lithochemical group

Quantile, Calcareous Metased- Mafic Felsic

in percent metasedimentary imentary igneous igneous

\begin{tabular}{lrrrr} 
& 1 ab & $c$ & a & bc \\
\hline 90 & 170 & 120 & 170 & 130 \\
50 (median) & 82 & 62 & 81 & 65 \\
10 & 23 & 21 & 43 & 25
\end{tabular}

1 Lithochemical populations with the same letter designation do not differ significantly at the 95-percent confidence level.

Significance level attained for the multiple-comparison test is 0.0001 .

\section{EXPLANATION}

LITHOCHEMICAL GROUPS

Calcareous metasedimentary [68]

Metasedimentary [415]

Mafic igneous

[95]

Felsic igneous [498]

[68] Number of samples

- Domestic well sampled for hardness

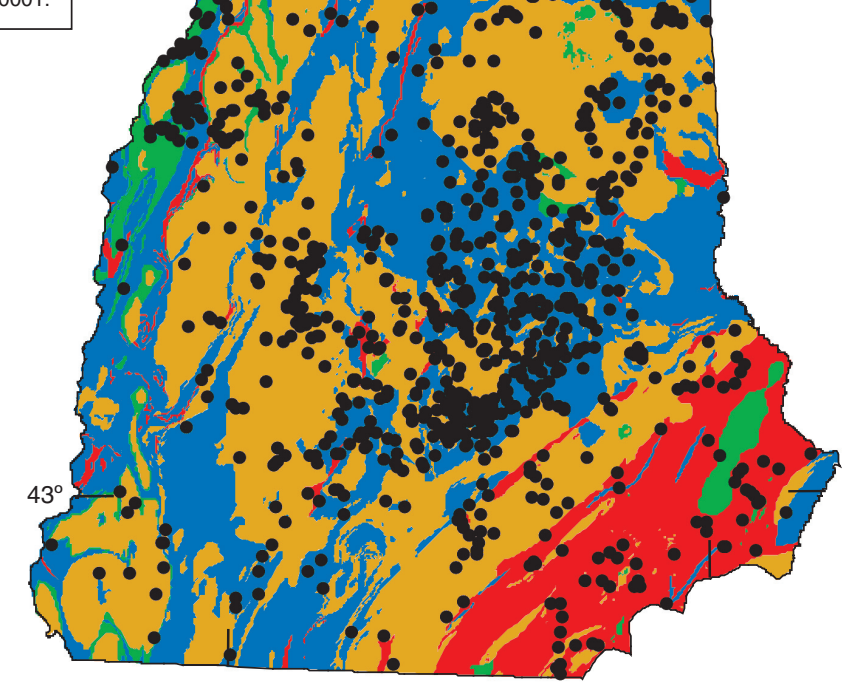

New Hampshire State plane feet projection

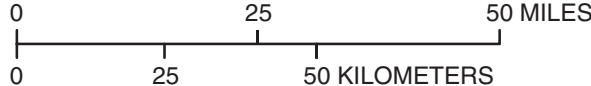

Figure 4. Location of domestic-bedrock-well sample sites in New Hampshire for total hardness concentration and statistical distribution of concentrations in relation to lithochemical groups. 


\section{Quality of Water in the Fractured-Bedrock Aquifer of New Hampshire}

\section{Iron}

Iron is a naturally occurring element in New Hampshire's ground water. Igneous rock minerals with high iron content in the State include pyroxenes, amphiboles, biotite, magnetite, and olivine. Iron in these minerals is in the ferrous $\left(\mathrm{Fe}^{2+}\right)$ oxidation state, but ferric $\left(\mathrm{Fe}^{3+}\right)$ also may be present, such as in magnetite, $\left(\mathrm{Fe} 3 \mathrm{O}_{4}\right)(\mathrm{Hem}, 1985)$. According to Hem (1985), iron dissolves as acidic rain water percolates through soil and rock. The iron that is released in this process can remain dissolved in the ground water or be precipitated. The chemical behavior of iron and its solubility in water depend strongly on the oxidation and $\mathrm{pH}$ conditions in which it occurs. Iron is not known to have effects on human health even if present in water in excessive amounts; however, it can form red precipitates that stain laundry and plumbing fixtures. A recommended SMCL for iron in public-water supplies to prevent staining is $300 \mu \mathrm{g} / \mathrm{L}$ (U.S. Environmental Protection Agency, 2002b).

The median of 1,078 iron samples from throughout the State is $135 \mu \mathrm{g} / \mathrm{L}(0.135 \mathrm{mg} / \mathrm{L})$. Thirty-one percent of these samples exceeded the SCML of $300 \mu \mathrm{g} / \mathrm{L}$ indicating that elevated iron concentrations in bedrock water is common.

Ground-water samples from the metasedimentary group have significantly greater concentrations of iron than do the felsic and mafic igneous groups (fig. 5). Ground-water samples with intermediate concentrations of iron in water from the calcareous metasedimentary group were not significantly different than concentrations in water from the other three lithochemical groups. Samples from wells in the metasedimentary group also had the highest percentage (37 percent) of ground-water samples exceeding $300 \mu \mathrm{g} / \mathrm{L}$. This percentage compares to 22 percent for the mafic igneous group, 26 percent for the calcareous metasediments, and 28 percent for the felsic igneous group.

In New Hampshire, water from the bedrock aquifer has greater concentrations of iron than does water from stratifieddrift aquifers. The median concentration of iron in water from bedrock wells is an order of magnitude greater $(135 \mu \mathrm{g} / \mathrm{L})$ than the reported median $(10 \mu \mathrm{g} / \mathrm{L})$ in stratified-drift aquifers (Medalie and Moore, 1995). 
Cumulative frequency plot of iron concentrations by lithochemical group. Gray area is less than the Secondary Maximum Contaminant Level of $\mathbf{3 0 0}$ micrograms per liter recommended by U.S. Environmental Protection Agency.

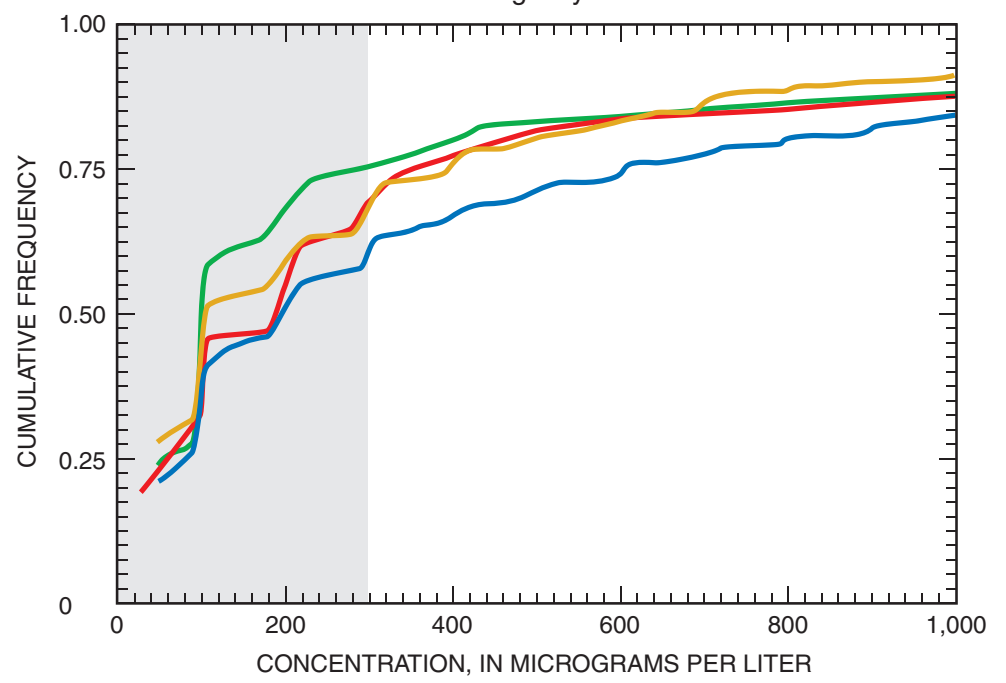

Iron

\section{(Domestic wells)}

\begin{tabular}{|c|c|c|c|c|}
\hline \multicolumn{5}{|c|}{$\begin{array}{l}\text { Distribution of iron concentrations by lithochemical group } \\
{[<\text {, less than] }}\end{array}$} \\
\hline $\begin{array}{l}\text { Quantile, } \\
\text { in percent }\end{array}$ & $\begin{array}{l}\text { Calcareous } \\
\text { metasedimentary } \\
{ }_{1} \mathrm{ab}\end{array}$ & $\begin{array}{l}\text { Metased- } \\
\text { imentary } \\
\quad \text { a }\end{array}$ & $\begin{array}{l}\text { Mafic } \\
\text { igneous } \\
\text { b }\end{array}$ & $\begin{array}{l}\text { Felsic } \\
\text { igneous } \\
\text { b }\end{array}$ \\
\hline 90 & 1,400 & 1,700 & 1,300 & 900 \\
\hline 50 (median) & 200 & 200 & 100 & 100 \\
\hline 10 & $<100$ & $<100$ & $<100$ & $<100$ \\
\hline \multicolumn{5}{|c|}{$\begin{array}{l}1 \text { Lithochemical populations with the same letter designation do not differ } \\
\text { significantly at the 95-percent confidence level. } \\
\text { Significance level attained for the multiple-comparison test is } 0.0011 \text {. }\end{array}$} \\
\hline
\end{tabular}

\section{EXPLANATION}

\section{LITHOCHEMICAL GROUPS}

Calcareous metasedimentary [68]

Metasedimentary [416]

Mafic igneous [95]

Felsic igneous [499]

[68] Number of samples

- Domestic well sampled for iron

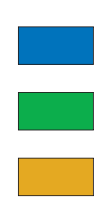

16]

9]

.
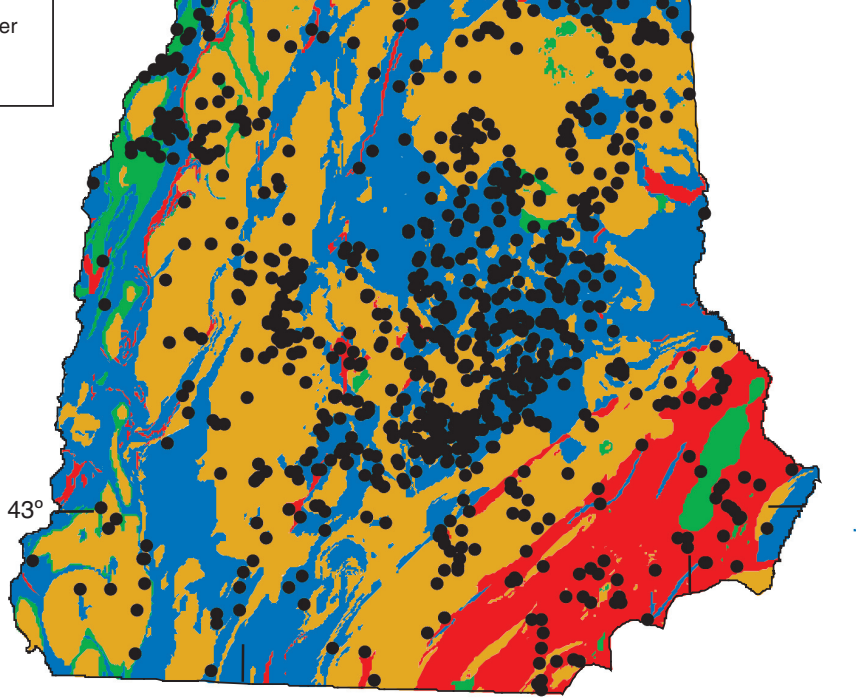

New Hampshire State plane feet projection

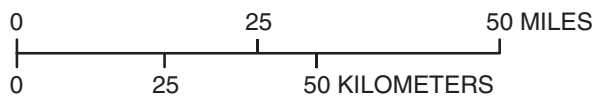

Figure 5. Location of domestic-bedrock-well sample sites in New Hampshire for total iron concentration and statistical distribution of concentrations in relation to lithochemical groups. 


\section{Manganese}

Manganese occurs naturally in New Hampshire's ground water and varies in concentration with the rock matrix through which the water flows. Manganese, like iron, is one of the most common elements in rocks and soils. Many igneous and metamorphic minerals contain manganese as a minor constituent (Hem, 1985). In New Hampshire, manganese is a major constituent of basalt and is found in pyroxene and amphibole minerals. According to Hem (1985), the chemistry of manganese is similar to iron in that both metals participate in reduction-oxidation processes in weathering environments. The most common forms of manganese in rocks and soils are oxides and hydroxides, which tend to strongly adsorb other metallic cations. Manganese is considered undesirable in water supplies because of the potential to deposit black oxide stains, clog fixtures, and cause a metallic taste. The recommended SMCL upper limit for manganese in public-water supplies in the United States is $50 \mu \mathrm{g} / \mathrm{L}$ (U.S. Environmental Protection Agency, 2002b).
The median of 1,076 manganese samples from throughout the State is $40 \mu \mathrm{g} / \mathrm{L}(0.04 \mathrm{mg} / \mathrm{L})$ with 40 percent of these samples exceeding the $50 \mu \mathrm{g} / \mathrm{L}$ SCML. Manganese concentrations are statistically different among the lithochemical groups (fig. 6). Ground-water samples from the metasedimentary group have higher manganese concentrations than do those either from the felsic or mafic igneous groups; samples from wells in calcareous metasedimentary rocks have water that statistically is not dissimilar to water from the other three lithochemical groups.

Water from the metasedimentary group also had the highest percentage ( 52 percent) of samples exceeding the SMCL of $50 \mu \mathrm{g} / \mathrm{L}$. Forty percent of the calcareous metasedimentary group exceeded the SMCL. This result compares to exceedences of 32 and 34 percent for the felsic and mafic igneous groups, respectively (fig. 6).

Water from the bedrock aquifer has concentrations of manganese that are similar to, or slightly less than, water from stratified-drift aquifers. The median value of manganese concentrations in water from stratified-drift aquifers in New Hampshire is $63 \mu \mathrm{g} / \mathrm{L}$ (Medalie and Moore, 1995). This result compares to a median manganese concentration of $40 \mu \mathrm{g} / \mathrm{L}$ in water from the bedrock aquifer. 
Cumulative frequency plot of manganese concentrations by lithochemical group. Gray area is less than the Secondary Maximum Contamnant Level of 50 micrograms per liter recommended by U.S. Environmental Protection Agency.

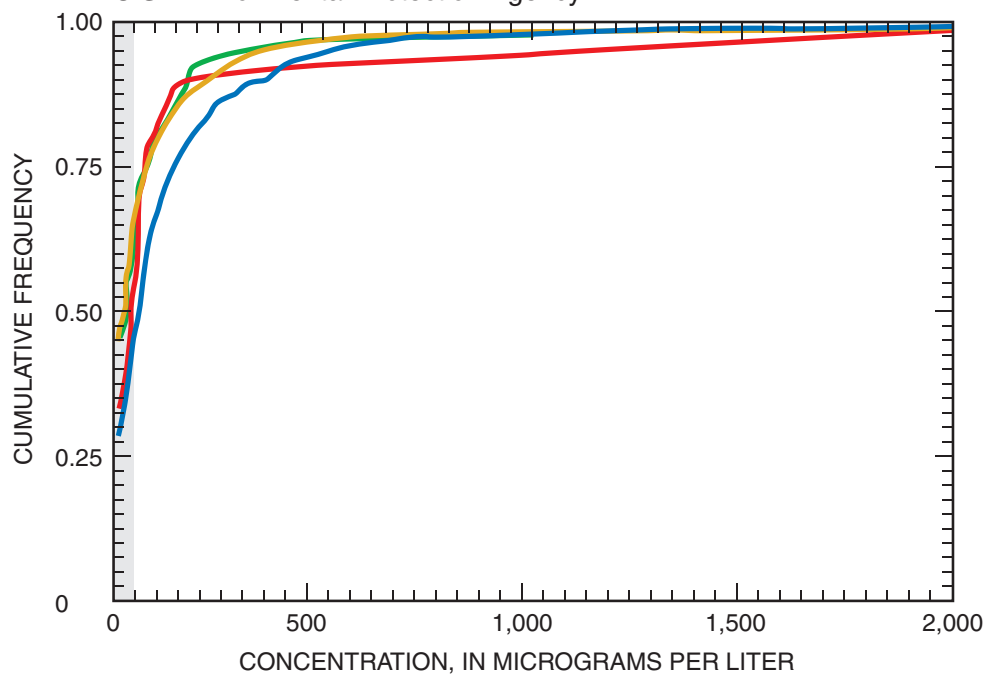

\section{Manganese (Domestic wells)}

\begin{tabular}{|c|c|c|c|c|}
\hline \multicolumn{5}{|c|}{$\begin{array}{l}\text { Distribution of manganese concentrations by } \\
\text { lithochemical group } \\
{[<\text {, less than }]}\end{array}$} \\
\hline $\begin{array}{l}\text { Quantile, } \\
\text { in percent }\end{array}$ & $\begin{array}{l}\text { Calcareous } \\
\text { metasedimentary } \\
{ }_{1} \text { ab }\end{array}$ & $\begin{array}{l}\text { Metased- } \\
\text { imentary } \\
\quad \text { a }\end{array}$ & $\begin{array}{c}\text { Mafic } \\
\text { igneous } \\
\text { b }\end{array}$ & $\begin{array}{l}\text { Felsic } \\
\text { igneous } \\
\text { b }\end{array}$ \\
\hline 90 & 170 & 330 & 180 & 220 \\
\hline 50 (median) & 40 & 60 & 30 & 26 \\
\hline 10 & $<30$ & $<30$ & $<30$ & $<30$ \\
\hline
\end{tabular}

\section{EXPLANATION}

\section{LITHOCHEMICAL GROUPS}

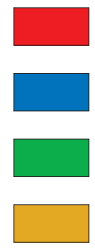

Calcareous metasedimentary [68]

Metasedimentary [415]

Mafic igneous

Felsic igneous [498]

[68] Number of samples

- Domestic well sampled for manganese

.

\section{(1)}

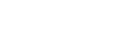




\section{Fluoride}

Fluoride is the negative ion of fluorine, an element that occurs commonly and naturally in rock minerals. Fluoride concentrations present in most natural waters generally are less than $1.0 \mathrm{mg} / \mathrm{L}$ because fluorine is relatively insoluble (Hem, 1985). Hem (1985) also reports that fluoride ions form strong complexes with many cations. In New Hampshire, various fluoride-containing minerals, such as fluorite $\left(\mathrm{CaF}^{2}\right)$, commonly are found. Large crystals of fluorite are found in Crawford Notch in the White Mountains (Hitchcock, 1878, part IV, p. 35) (fig. 7). Fluorite has a low solubility and occurs in igneous, metamorphic, and sedimentary rock. Other fluoride-containing minerals, commonly found in New Hampshire, include apatite, amphiboles (such as hornblende), and some micas.

Fluoride in drinking water is beneficial at concentrations less than $1.2 \mathrm{mg} / \mathrm{L}$ for dental protection. The Federal Centers for Disease Control have recommended 1.0 to $1.2 \mathrm{mg} / \mathrm{L}$ as the optimum beneficial concentration of fluoride in drinking water for dental protection (New Hampshire Department of Environmental Services, 2001). Drinking water with fluoride concentrations greater than $2.0 \mathrm{mg} / \mathrm{L}$ can cause staining of tooth enamel; at concentrations greater than $4.0 \mathrm{mg} / \mathrm{L}$, fluoride may cause bone disease (skeletal fluorosis) (New Hampshire Department of Environmental Services, 2001; U.S. Environmental Protection Agency, 2002a). As a result, the USEPA has established a MCL of $4.0 \mathrm{mg} / \mathrm{L}$ for fluoride and a SMCL of $2.0 \mathrm{mg} / \mathrm{L}$.

The median of 1,138 fluoride samples from throughout the State is $0.40 \mathrm{mg} / \mathrm{L}$ with 2 percent of these samples exceeding the $4.0 \mathrm{mg} / \mathrm{L} \mathrm{MCL}$ and 9 percent exceeding the $2.0 \mathrm{mg} / \mathrm{L}$ SCML. Ground-water samples from the felsic igneous group have significantly greater concentrations of fluoride than do those from the other groups (fig. 8). Fluoride in ground-water samples from the mafic igneous and metasedimentary groups were similar to one another, and ground-water samples from the calcareous metasedimentary group had significantly lower concentrations of fluoride than the other groups.

Wells in the felsic igneous lithochemical group also had the highest percentage of ground-water samples exceeding USEPA drinking-water standards; 13 percent were greater than the SMCL of $2 \mathrm{mg} / \mathrm{L}$ and 3 percent were greater than the MCL of $4 \mathrm{mg} / \mathrm{L}$. Wells in the calcareous metasedimentary group had the fewest number of samples exceeding the standards with just 1 percent exceeding the SMCL and none exceeding the MCL.

Water from the bedrock aquifer in New Hampshire typically has higher concentrations of fluoride than does water from stratified-drift aquifers. The median concentration of fluoride in water from the bedrock aquifer is $0.4 \mathrm{mg} / \mathrm{L}$ as compared to a median concentration of $0.1 \mathrm{mg} / \mathrm{L}$ for water from stratified-drift aquifers (Medalie and Moore, 1995).

\section{EXPLANATION}

LITHOCHEMICAL GROUPS

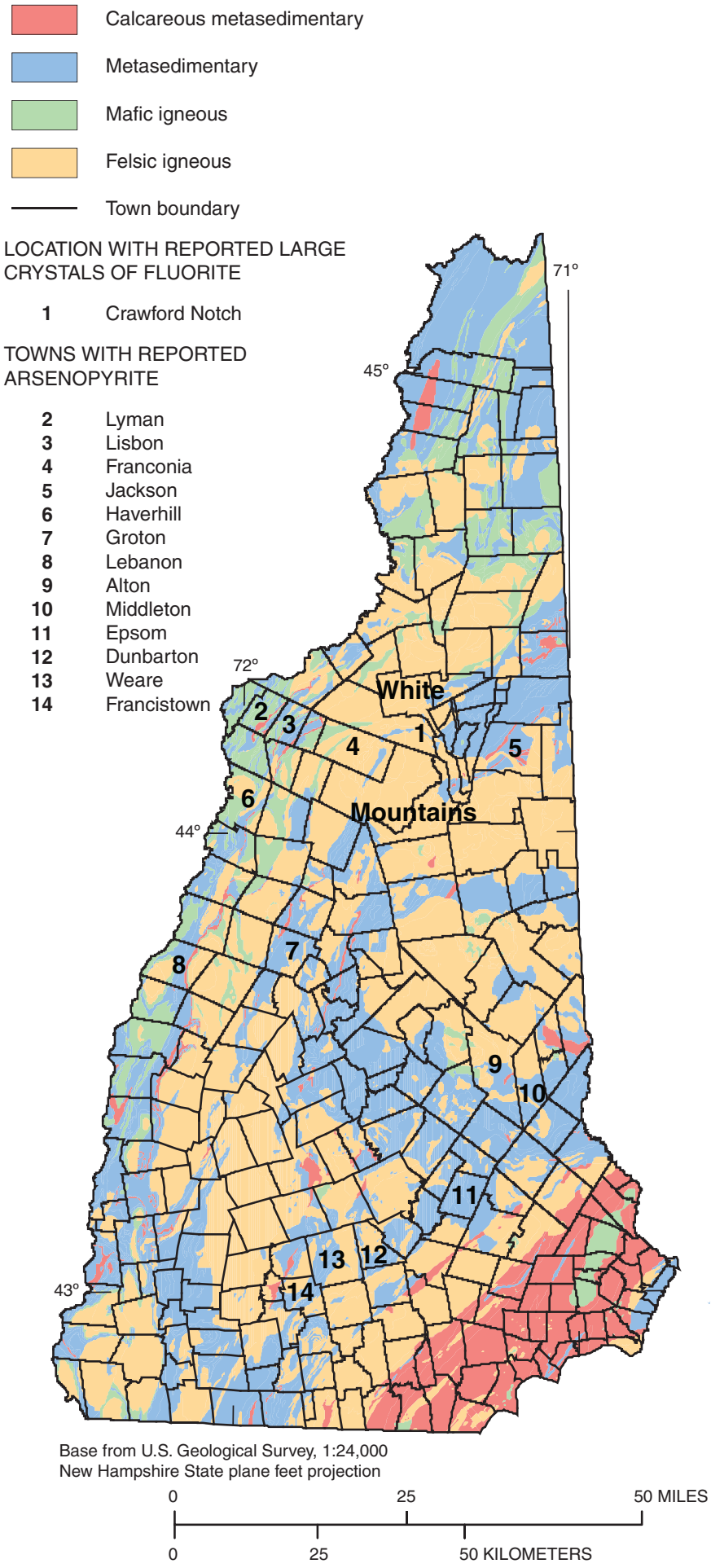

Figure 7. Location of Crawford Notch with reported large crystals of fluorite, and towns in New Hampshire with reported noteworthy locations with arsenopyrite, shown in relation to lithochemical groups. 
Cumulative frequency plot of fluoride concentrations by lithochemical group. Darker gray area is less than the Secondary Maximum Contaminant Level of 2 milligrams per liter recommended by

U.S. Environmental Protection Agency. Lighter gray area is less than the Maximum Contaminant Level of 4 milligrams per liter required by U.S. Environmental Protection Agency for public-water supplies.

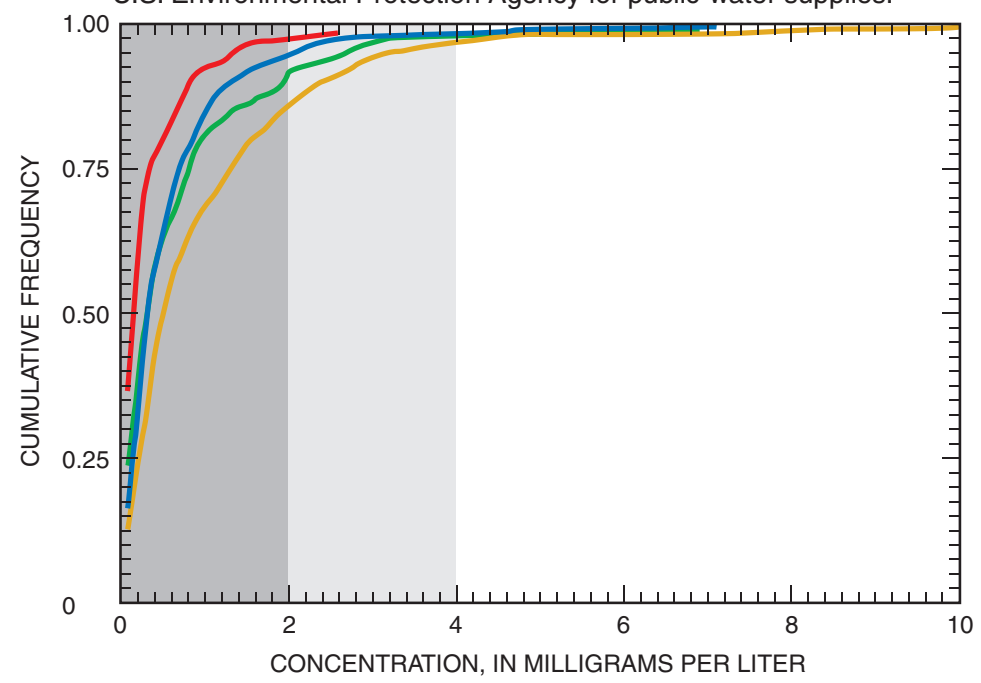

\section{Fluoride (Domestic wells)}

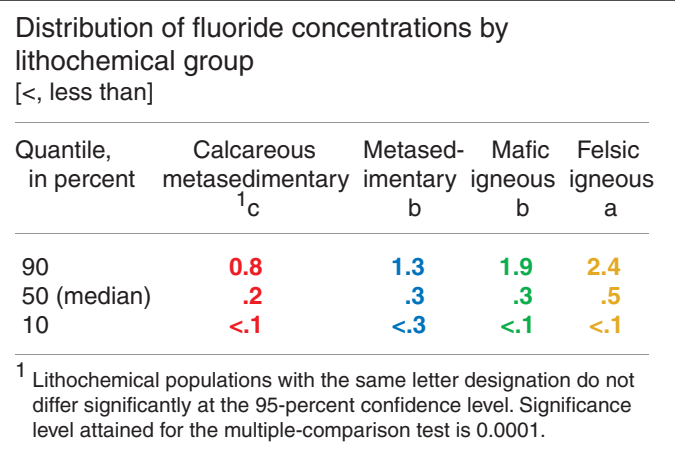

\section{EXPLANATION}

\section{LITHOCHEMICAL GROUPS}

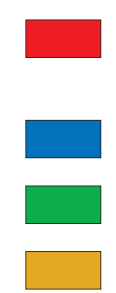

Calcareous metasedimentary [71] (lowest)

Metasedimentary [439]

Mafic igneous [101]

Felsic igneous [527]

[71] Number of samples

- Domestic well sampled for fluoride

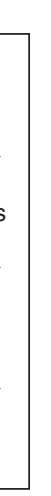

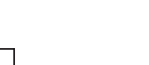




\section{Arsenic}

Arsenic, a highly undesirable impurity in water supplies because of its potentially adverse effect on human health, occurs naturally in New Hampshire. Arsenic may be found in metal arsenide and sulfide minerals, and it can be present as native arsenic as an accessory element in sulfide ore deposits (Hem, 1985). Arsenic, in the form of arsenopyrite or other arsenic-rich pyrites, is sufficiently plentiful in New Hampshire to have justified small-scale mining in the past. Localities of note where arsenic minerals have been found are in "Jackson, Francistown, Haverhill, Lebanon, Weare, Groton, Lisbon, Lyman, Middleton, Dunbarton, Epsom, and Alton" (Hitchcock, 1878, part V, p. 68) and Franconia, N.H. (Hurlbut, 1971, p. 267) (fig. 9). New Hampshire also has some of the few localities in the United States (in Haverhill and Jackson) where native arsenic has been found "in thin layers in a dark blue mica schist, associated with iron and arsenical pyrites" (G.W. Hawes, in Hitchcock, 1878, part IV, p. 25). Widespread high arsenic concentrations in ground water are most commonly caused by release from phyllosilicate, iron oxide, and sulfide minerals (Welch and Ayotte, 2002).

Various geochemical processes regulate arsenic concentrations found in ground water. Adsorption of arsenic by hydrous iron oxide, or in combination with sulfide in reduced bottom mud, are processes that can maintain concentrations of arsenic at low levels in water (Hem, 1985). Aerobic geochemical conditions, in particular, appear to inhibit the solubility of arsenic in ground water. On the basis of the analyses of water samples from more than 100 domestic bedrock wells in Eastern New England, Ayotte and others (2003) found that dissolved arsenic concentrations were greatest in waters with high $\mathrm{pH}$ and low dissolved-oxygen concentrations. Few samples with dissolved-oxygen concentrations greater than $1 \mathrm{mg} / \mathrm{L}$ had arsenic concentrations greater than $1 \mu \mathrm{g} / \mathrm{L}$. Conversely, anaerobic conditions, which can be associated with landfill leachates, tend to increase the solubility and mobility of arsenic in ground water (Colman and others, 2002; Wilkin and others, 2002).

Since 1999, a number of previous studies assessed the presence of arsenic in ground waters of New England and, collectively, these studies indicate that ground water in parts of New Hampshire are susceptible to elevated concentrations (above $10 \mu \mathrm{g} / \mathrm{L}$ ) of arsenic (Ayotte and others, 2003; Ayotte and others, 2002; Montgomery and others, 2003; and Peters and others, 2002). These studies were stimulated by the known occurrence of elevated concentrations of arsenic in ground water from parts of New England and the change of the arsenic MCL from $50 \mu \mathrm{g} / \mathrm{L}$ to $10 \mu \mathrm{g} / \mathrm{L}$ (New Hampshire Department of Environmental Services, 2002; U.S. Environmental Protection Agency, 2002a). Ayotte and others (2003) reported that nearly 30 percent of domestic wells sampled in calcareous metasedimentary bedrock in eastern New England-including parts of New Hampshire-contained water with arsenic concentrations greater than $10 \mu \mathrm{g} / \mathrm{L}$; this percentage compares to 7 percent of the sampled wells in other types of bedrock and 3 percent of wells in stratified-drift aquifers. Ayotte and others estimated that about 103,000 people in Eastern New England with domestic wells could have water with arsenic above $10 \mu \mathrm{g} / \mathrm{L}$. Ayotte and others (1999) noted similar relations between arsenic concentrations in the water from publicsupply wells in Eastern New England.

Montgomery and others (2003) sampled 353 randomly selected private bedrock wells for arsenic in 3 southeastern counties of New Hampshire (Hillsboro, Rockingham, and Strafford Counties) to better define the presence of arsenic in ground water from bedrock. Major findings from this study are (1) 19 percent of wells tested in the three counties had concentrations of arsenic that exceed the $10 \mu \mathrm{g} / \mathrm{L} \mathrm{MCL}$ for public-water supplies, (2) the spatial distribution of arsenic concentrations that exceed $10 \mu \mathrm{g} / \mathrm{L}$ relates to geology, and (3) less than 14 percent of the wells had been previously tested for arsenic.

The distribution of bedrock types throughout much of New England closely matches, at a gross scale, the areas of elevated arsenic in ground water (Robinson and Ayotte, 2002). In central New Hampshire, the geographic distribution of elevated arsenic concentrations in the bedrock aquifer correlates with the presence of pegmatites that border the Concord Granite and which intrude metasedimentary rocks (Peters and others, 2002). Arsenic concentrations of the rock matrix in the pegmatites average $9.6 \mathrm{mg} / \mathrm{kg}$, which is much higher than concentrations in the rock matrix of associated granites $(0.24 \mathrm{mg} / \mathrm{kg})$ and metasedimentary rocks $(0.8 \mathrm{mg} / \mathrm{kg})$. Peters and others (2002) proposed that pegmatites have the highest arsenic concentrations because the pegmatites are the last to crystallize during formation.

The source of the arsenic in ground water of New England is thought to be predominantly natural, originating from minerals within the rocks of the region (Robinson and Ayotte, 2002; Ayotte and others, 2003). Former pesticide use, treated lumber, and manufacturing also are sources of arsenic that may contribute to ground-water contamination (Ayotte and others, 2002; Robinson and Ayotte, 2002). In Maine, Loiselle and others (2002) concluded that the arsenic concentration of ground water is most likely the result of both natural processes and human activities.

Using well data from the NHDES Laboratory, the median of 191 arsenic samples from domestic wells throughout the State is less than $5.0 \mu \mathrm{g} / \mathrm{L}$, with 21 percent of these samples exceeding the $10 \mu \mathrm{g} / \mathrm{L} \mathrm{MCL}$. These samples do not show statistically significant differences in arsenic concentrations among lithochemical units (fig. 8); this may be because of the limited number of samples in each lithochemical unit-just 15 samples from calcareous metasedimentary group, for example. Graphically, however, the calcareous metasedimentary group appears to have arsenic concentrations greater than the other groups.

Arsenic data from the 357 public-supply bedrock well samples have a median concentration of less than $5 \mu \mathrm{g} / \mathrm{L}$ with 12 percent exceeding the MCL of $10 \mu \mathrm{g} / \mathrm{L}$. These data indicate 
Cumulative frequency plot of arsenic concentrations by lithochemical group for domestic bedrock wells. Gray area is less than the Maximum Contaminant Level of 10 micrograms per liter required by U.S.

Environmental Protection Agency for public-water supplies.

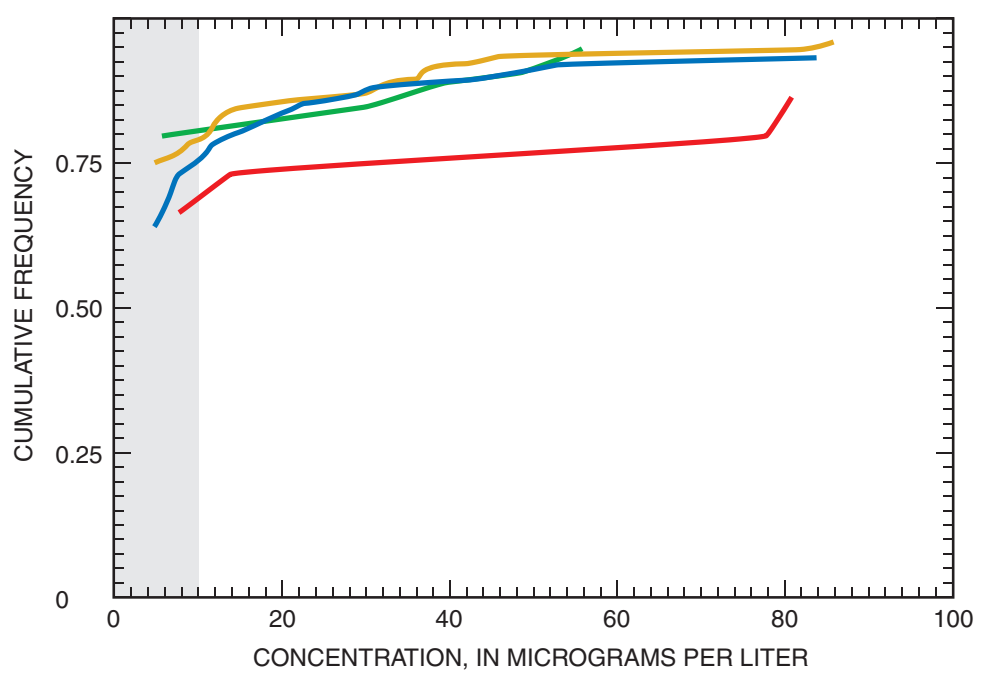

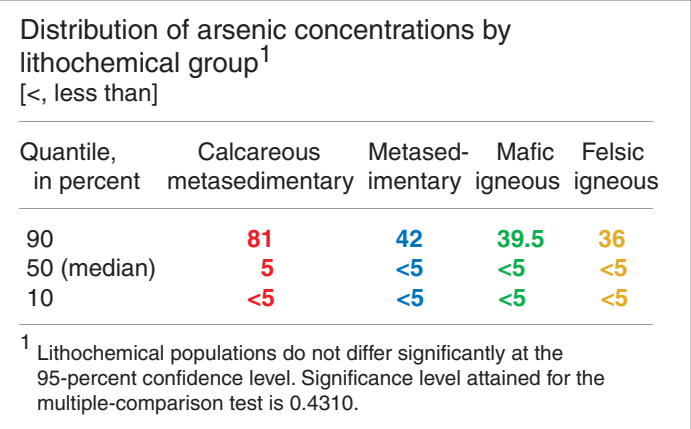

\section{EXPLANATION}

\section{LITHOCHEMICAL GROUPS}

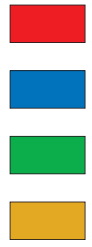

Calcareous metasedimentary [15]

Metasedimentary [77]

Mafic igneous [20]

Felsic igneous [79]

[15] Number of samples

- Domestic well sampled for arsenic

\section{Arsenic \\ (Domestic wells)}
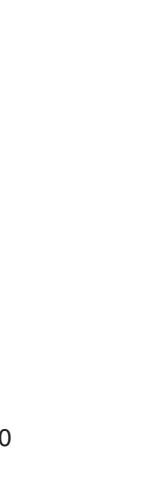
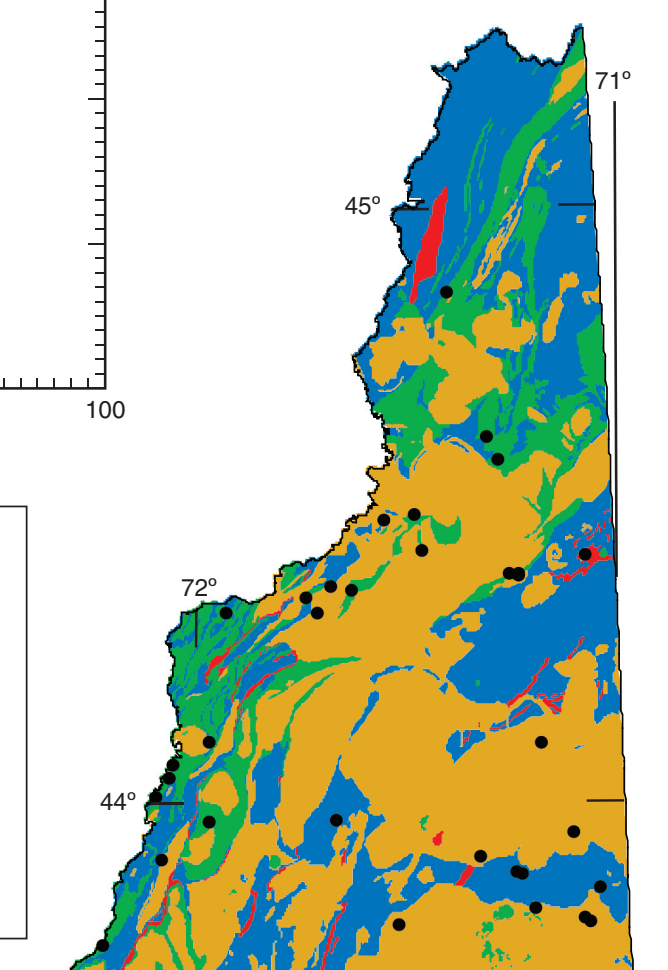

(a) 
statistically significant differences in arsenic concentrations among lithochemical units. Ground-water samples from the calcareous metasedimentary group have significantly greater concentrations of arsenic than samples from the other groups with the exception of the mafic igneous group. This result may be because of the lack of data with only eight public-supply bedrock wells in the mafic igneous group (fig. 10). The occurrence of high arsenic concentrations in public-supply wells in the calcareous metasedimentary bedrock of New Hampshire is similar to results reported by Ayotte and others (1999), and is expected because some of the arsenic data are used in both studies.
The calcareous metasedimentary group, for domestic and public-supply wells, had the highest percentage (27 and 21 percent, respectively) of ground-water samples exceeding the USEPA drinking-water MCL of $10 \mu \mathrm{g} / \mathrm{L}$ arsenic. These percentages compare to 23 and 9 percent for the domestic and the public-supply-well samples, respectively, from the metasedimentary group; 20 and 10 percent, respectively, for samples from the felsic igneous group, and 15 and 0 percent, respectively, for samples from the mafic igneous group.

Arsenic data for samples from wells in stratified-drift aquifers are not available from Medalie and Moore (1995); however, Ayotte and others (1999) report that the occurrence of arsenic concentrations of $5 \mu \mathrm{g} / \mathrm{L}$ or greater in public-watersupply bedrock wells was significantly greater than the occurrence in stratified-drift aquifer wells. 
Cumulative frequency plot of arsenic concentrations by lithochemical group for public-supply bedrock wells. Gray area is less than the Maximum Contaminant Level of 10 micrograms per liter required by U.S. Environmental Protection Agency for public-water supplies.

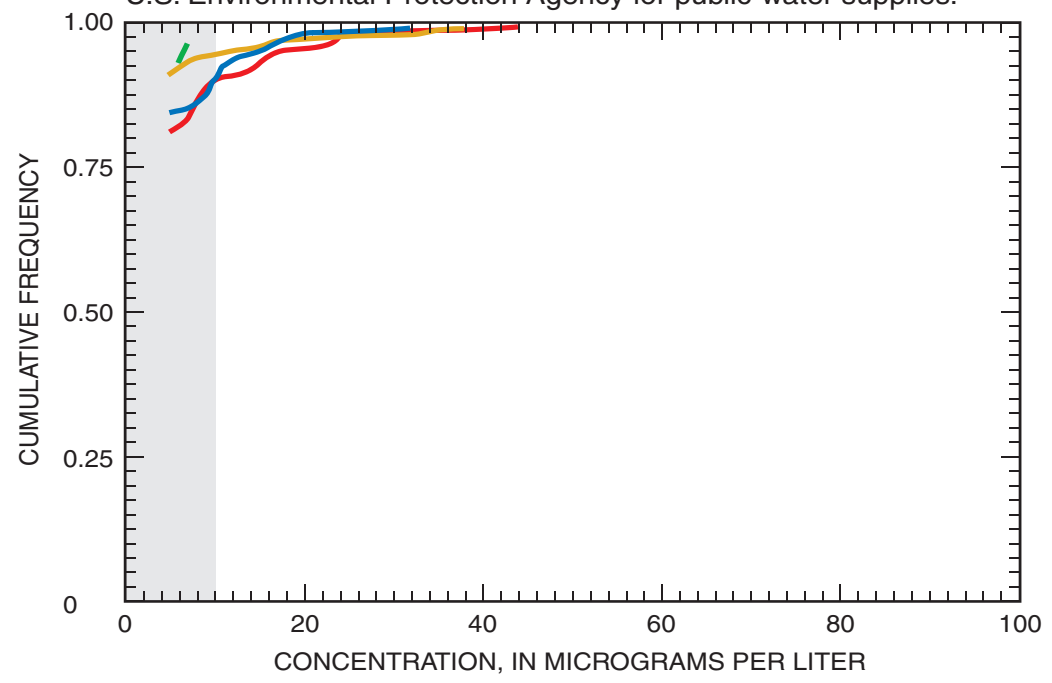

\begin{tabular}{|c|c|c|c|c|}
\hline $\begin{array}{l}\text { Quantile, } \\
\text { in percent }\end{array}$ & $\begin{array}{c}\text { Calcareous } \\
\text { metasedimentary } \\
{ }_{1} \mathrm{a}\end{array}$ & $\begin{array}{l}\text { Metased- } \\
\text { imentary } \\
\text { b }\end{array}$ & $\begin{array}{c}\text { Mafic } \\
\text { igneous } \\
\text { ab }\end{array}$ & $\begin{array}{c}\text { Felsic } \\
\text { igneous } \\
\text { b }\end{array}$ \\
\hline 90 & 18 & 10 & 7 & 11 \\
\hline 50 (median) & $<5$ & $<5$ & $<5$ & $<5$ \\
\hline 10 & $<5$ & $<5$ & $<5$ & $<5$ \\
\hline
\end{tabular}

\section{EXPLANATION}

\section{LITHOCHEMICAL GROUPS}

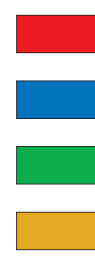

Calcareous metasedimentary [76]

Metasedimentary [102]

Mafic igneous

Felsic igneous [171]

[76] Number of samples

- Public-supply well sampled for arsenic

\section{Arsenic \\ (Public wells)}$$
\text { 西 }
$$
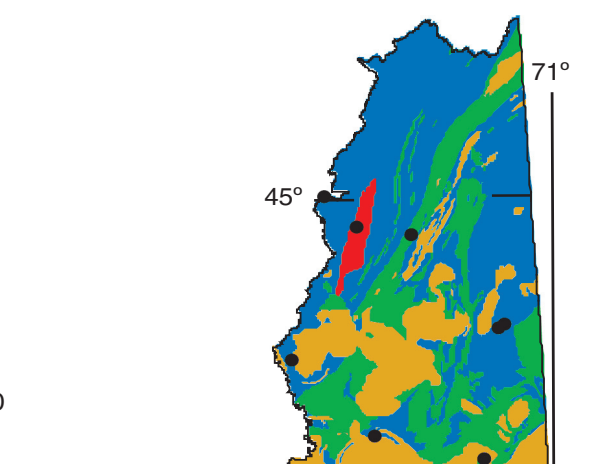


\section{Radon}

Radon is a naturally occurring radioactive gas that is part of the uranium decay chain. Isotopes of radon are produced from the decay of radium isotopes 223,224 , and 226. Radon222 produced in the decay of radium-226 has a half-life of 3.8 days and is the only radon isotope of importance in the environment because the other radon isotopes have half-lives of less than a minute (Hem, 1985). Radon, in addition to being transported in the gas phase, is soluble in water. According to Hem (1985), small amounts are present in the atmosphere; however, large amounts (when compared to the atmosphere) are present in gases below the land surface. As a result, radon can enter buildings and homes through foundations and wellwater systems. Radon-222 decays through a series of shortlived daughter products to lead-210, which has a half-life of 21.8 years.

Two standards presently (2004) are being proposed by USEPA for radon in public-supply waters (U.S. Environmental Protection Agency, 1999). A standard of 4,000 pCi/L is proposed under the "multimedia mitigation" program (U.S. Environmental Protection Agency, 1999), which takes into consideration air and water sources of radon. Under this program, if the contribution in air is low, or treated to be low, higher concentrations in water are applied than otherwise would be allowed. When multimedia mitigation is not applied, the proposed USEPA MCL is $300 \mathrm{pCi} / \mathrm{L}$ for water. The State of New Hampshire recommends that homeowners take steps to lower indoor radon-air concentrations when these concentrations equal or exceed $4 \mathrm{pCi} / \mathrm{L}$ in the lowest part of the home (New Hampshire Department of Health and Human Services, 2004).

The median air-radon concentration, on the basis of data from 3,943 single family homes with bedrock wells, was

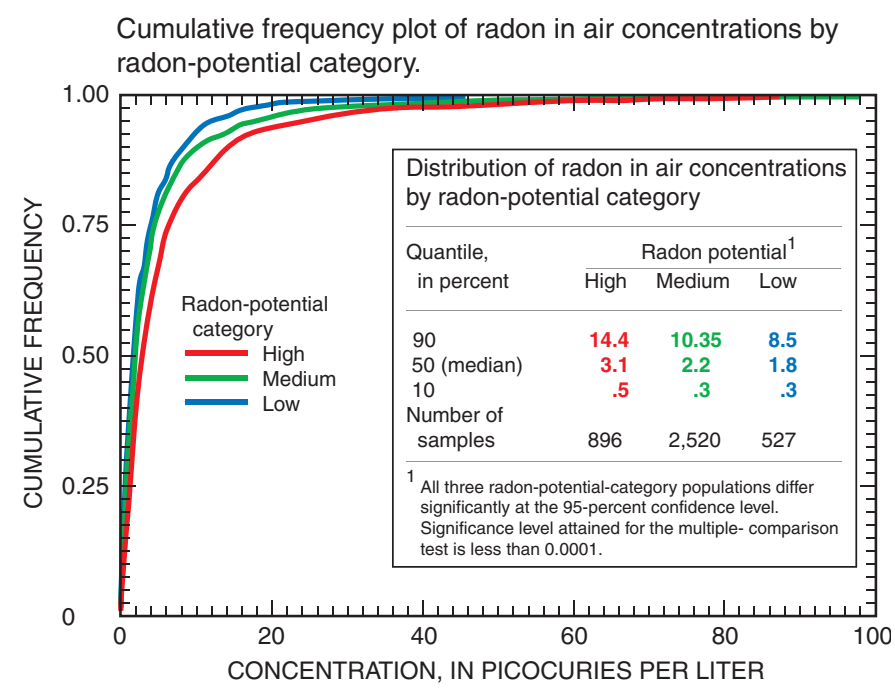

Figure 11. Statistical distribution of radon in air concentrations from single family homes with drilled wells in New Hampshire in relation to radon-potential categories.
$2.2 \mathrm{pCi} / \mathrm{L}$. Air-radon concentrations are statistically different when grouped by the radon-potential categories (high, medium, and low) (fig. 11) with the highest concentrations associated with the high radon-potential category. These results indicate that the grouping of bedrock into radon-potential categories can be useful for determining where high airradon concentrations are likely to be present.

The median radon concentrations in ground-water samples from 221 domestic bedrock wells is $2,600 \mathrm{pCi} / \mathrm{L}$, this compares to a median concentration of 2,000 pCi/L from 310 public-water-supply well samples. For the domestic and public-water-supply wells, radon concentrations were higher in bedrock grouped in the high radon-potential category than in the bedrock grouped as medium or low radon-potential categories (figs. 12 and 13). However, statistical differences in the domestic and public-supply-well data are not identified between the medium and low radon-potential categories. The lack of statistical difference may be because of the small number of samples in the low radon-potential categories for domestic and public-supply wells (30 and 45, respectively). By use of the generalized categories of radon potential, distinct differences in radon concentrations are identified from all three databases - air, domestic ground water, and publicsupply ground water (Moore and others, 2000).

Nearly all of the ground-water samples from the bedrock aquifer in New Hampshire fail to meet the proposed USEPA standard of $300 \mathrm{pCi} / \mathrm{L}$ when multimedia mitigation is not implemented. All of the water samples from the domestic and public-supply bedrock wells in the high-radon potential exceeded $300 \mathrm{pCi} / \mathrm{L} ; 97$ and 98 percent of the water samples from the domestic and public-supply bedrock wells, respectively, in the medium radon-potential category exceeded $300 \mathrm{pCi} / \mathrm{L}$, and 90 and 89 percent of the water samples, from domestic and public-supply bedrock wells, respectively, in the low radon-potential category exceeded $300 \mathrm{pCi} / \mathrm{L}$.

Many (40 and 30 percent) of the ground-water samples from the bedrock aquifer from domestic and public-supply bedrock wells, respectively, also fail to meet the proposed standard of 4,000 pCi/L (when multimedia mitigation is implemented). In the high radon-potential category, 70 and 50 percent of the water samples from the domestic and publicsupply bedrock wells, respectively, exceeded 4,000 pCi/L; in the medium radon-potential category, 34 and 27 percent from the domestic and public-supply bedrock wells exceeded $4,000 \mathrm{pCi} / \mathrm{L}$, respectively; and in the low radon-potential category, 17 and 16 percent from the domestic and public-supply bedrock wells exceeded 4,000 pCi/L, respectively.

Radon concentrations in the water of bedrock aquifers typically are greater than the concentrations in stratified-drift aquifers (Hall and others, 1985, and Boudette, 1994). Hall and others (1985) reported that general ranges of radon in glacial deposits (including stratified drift) are less than $1,000 \mathrm{pCi} / \mathrm{L}$. Data on radon concentrations in water from stratified-drift aquifers (Medalie and Moore, 1995) were not available for comparison to the bedrock radon data presented in this report. 


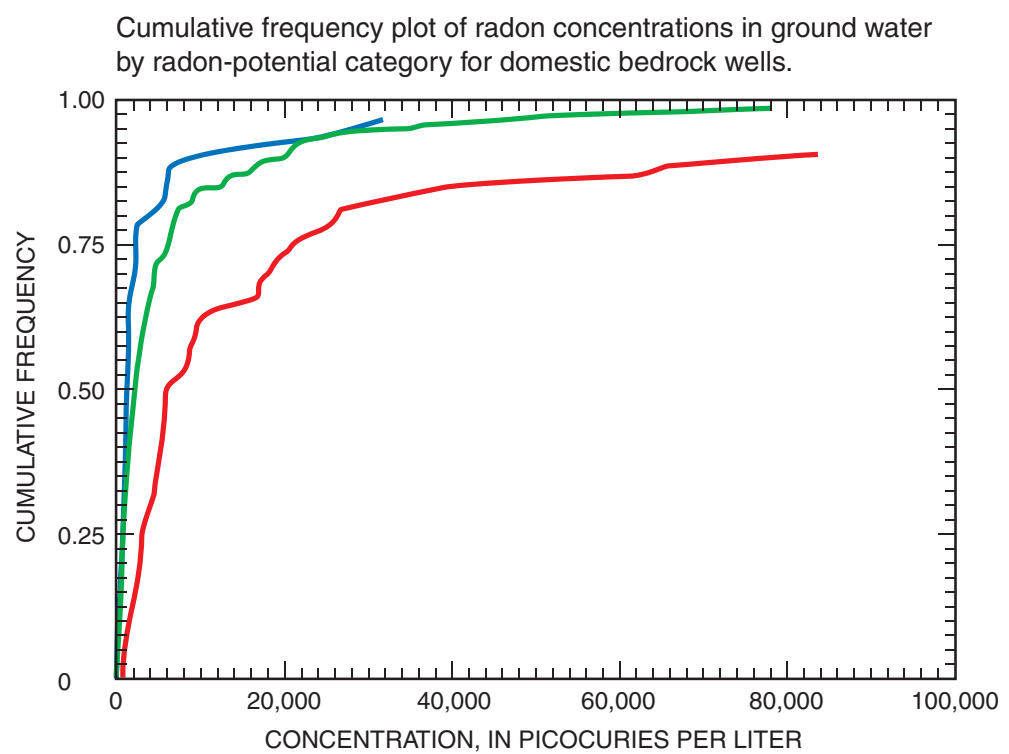

\section{Radon (Domestic wells)}

\begin{tabular}{|c|c|c|c|}
\hline \multicolumn{4}{|c|}{$\begin{array}{l}\text { Distribution of radon in water } \\
\text { concentrations by radon-potential category }\end{array}$} \\
\hline \multirow{2}{*}{$\begin{array}{l}\text { Quantile, } \\
\text { in percent }\end{array}$} & \multicolumn{3}{|c|}{ Radon potential } \\
\hline & $\begin{array}{l}\text { High } \\
1_{\mathrm{a}}\end{array}$ & $\begin{array}{l}\text { Medium } \\
\mathrm{b}\end{array}$ & $\begin{array}{c}\text { Low } \\
b\end{array}$ \\
\hline 90 & 65,700 & 19,500 & 6,300 \\
\hline 50 (median) & 5,900 & 2,250 & 1,350 \\
\hline 10 & 1,400 & 620 & 300 \\
\hline \multicolumn{4}{|c|}{$\begin{array}{l}1 \text { Radon-potential-category populations with the same } \\
\text { letter designation do not differ significantly at the } \\
95 \text {-percent confidence level. Significance level } \\
\text { attained for the multiple-comparison test is }<0.0001 \text {. }\end{array}$} \\
\hline
\end{tabular}

\section{EXPLANATION}

\section{RADON-POTENTIAL CATEGORIES}

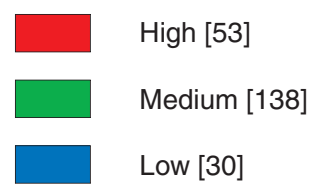

[53] Number of samples

- Domestic well sampled for radon

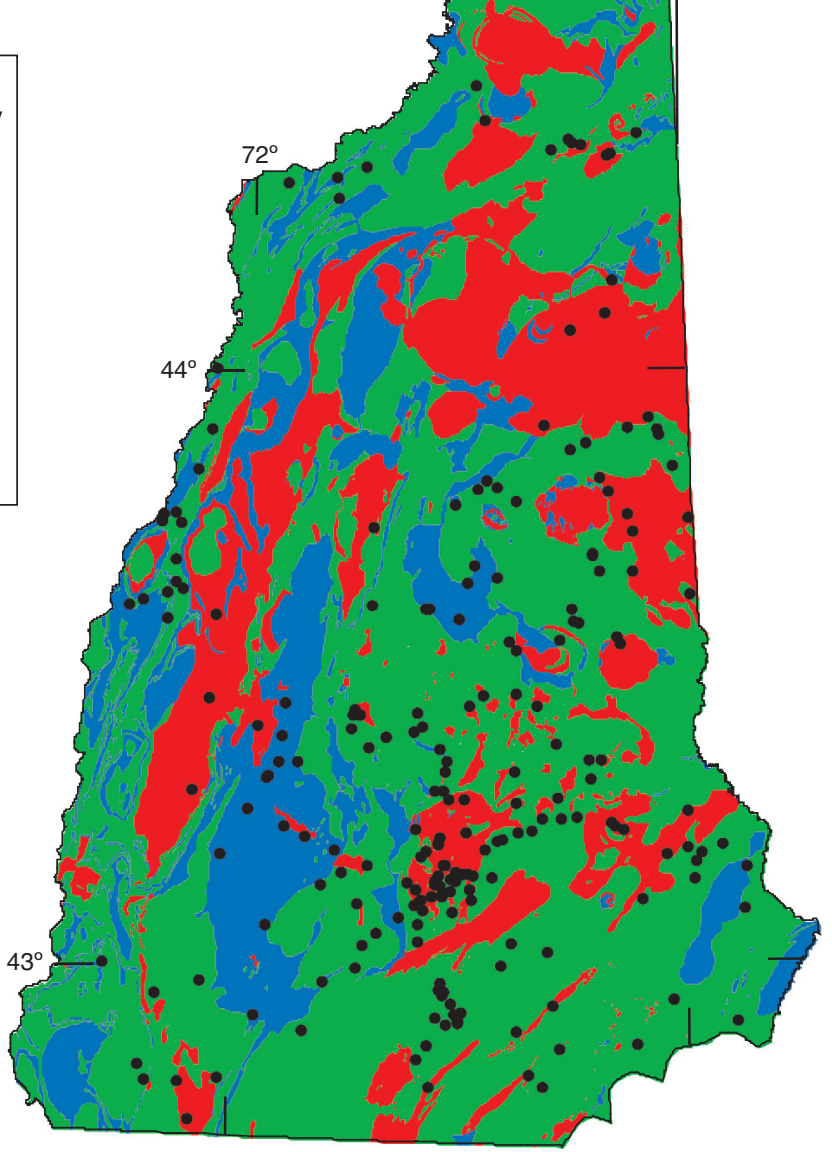

New Hampshire State plane feet projection

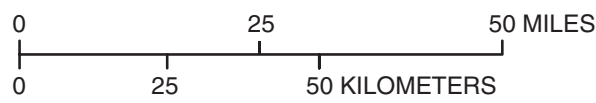

Figure 12. Location of domestic-bedrock-well sample sites in New Hampshire for radon concentration in ground water and statistical distribution of concentrations in relation to radon-potential categories. 
Cumulative frequency plot of radon concentrations in ground water by radon-potential category for public-supply bedrock wells.

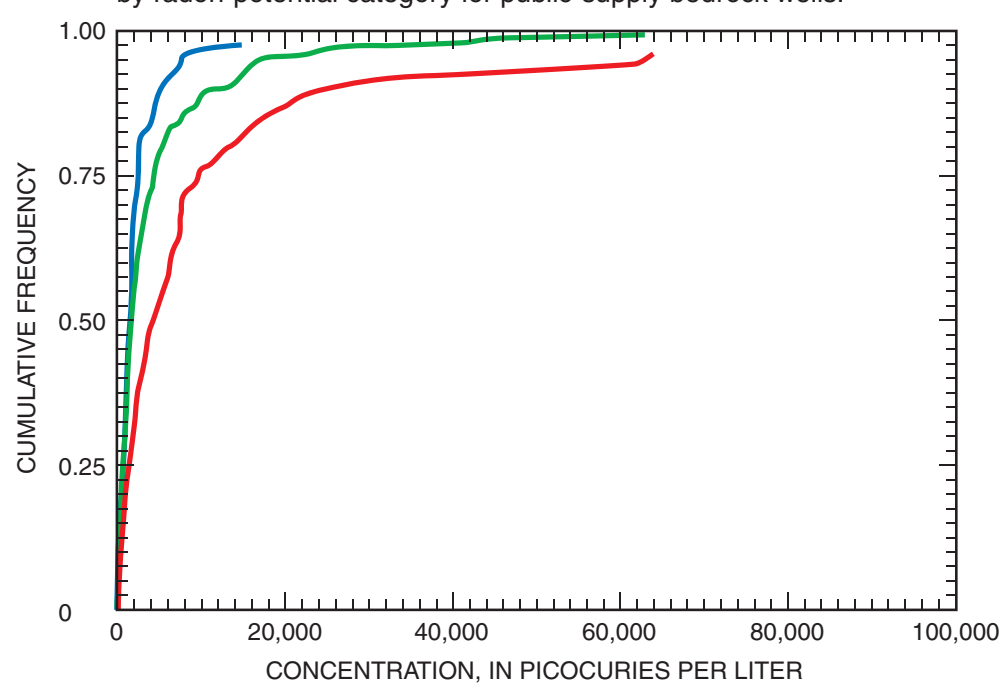

\section{Radon (Public wells)}

\begin{tabular}{|c|c|c|c|}
\hline \multicolumn{4}{|c|}{$\begin{array}{l}\text { Distribution of radon in water } \\
\text { concentrations by radon-potential category }\end{array}$} \\
\hline \multirow{2}{*}{$\begin{array}{l}\text { Quantile, } \\
\text { in percent }\end{array}$} & \multicolumn{3}{|c|}{ Radon potential } \\
\hline & $\begin{array}{l}\text { High } \\
1 \mathrm{a}\end{array}$ & $\begin{array}{l}\text { Medium } \\
\mathrm{b}\end{array}$ & $\begin{array}{c}\text { Low } \\
b\end{array}$ \\
\hline 90 & 22,000 & 11,000 & 5,400 \\
\hline 50 (median) & 4,200 & 1,800 & 1,800 \\
\hline 10 & 560 & 560 & 290 \\
\hline \multicolumn{4}{|c|}{$\begin{array}{l}1 \text { Radon-potential-category populations with the same } \\
\text { letter designation do not differ significantly at the } \\
95-\text { percent confidence level. Significance level } \\
\text { attained for the multiple-comparison test is } 0.0004 \text {. }\end{array}$} \\
\hline
\end{tabular}

\section{EXPLANATION}

\section{RADON-POTENTIAL CATEGORIES}

High [54]

Medium [211]

Low [45]

[54] Number of samples

- Public-supply well sampled for radon

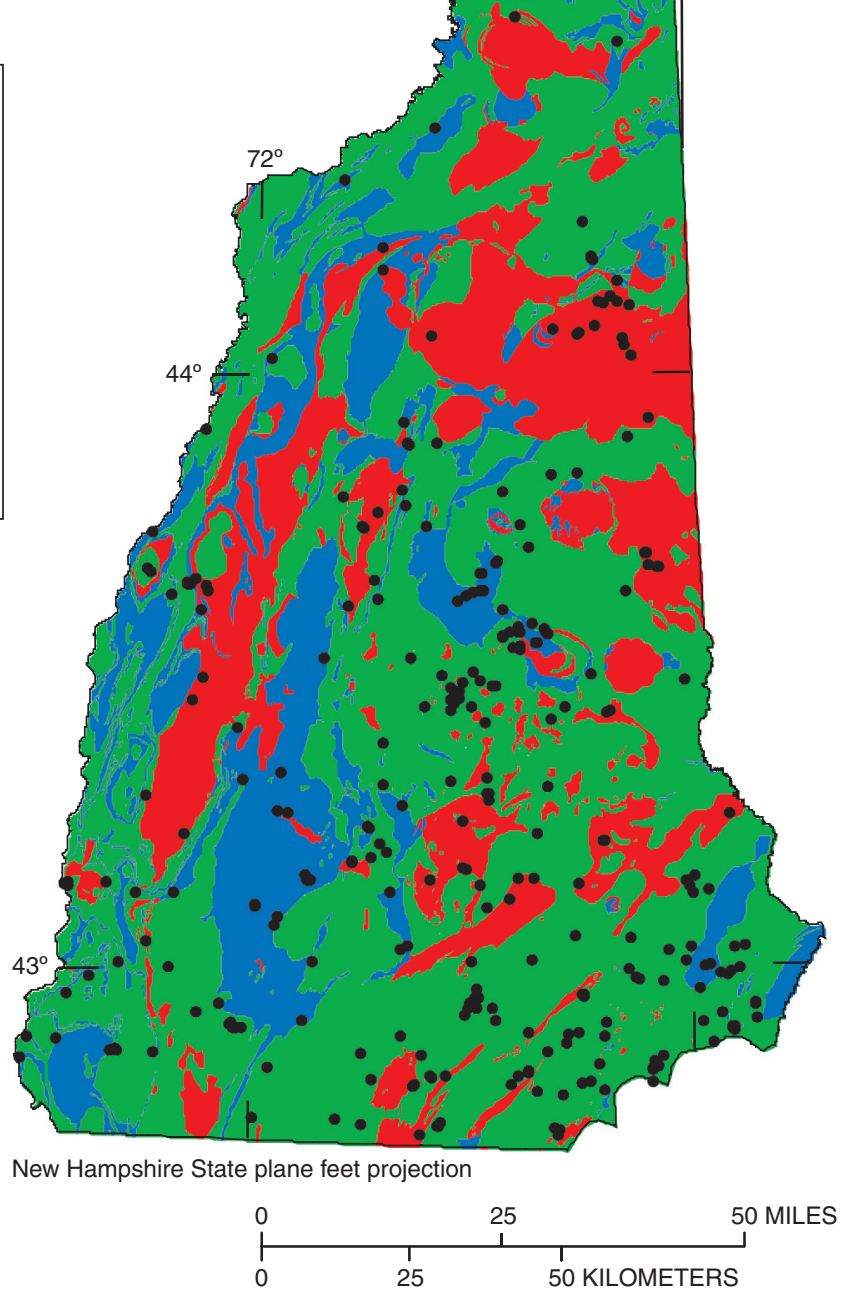

Figure 13. Location of public-supply bedrock-well sample sites in New Hampshire for radon concentration in ground water and statistical distribution of concentrations in relation to radon-potential categories. 


\section{Summary and Conclusions}

Many New Hampshire communities are looking to the fractured crystalline bedrock aquifer for additional water supplies. Understanding the variability of water quality within the bedrock aquifer may be an important consideration when evaluating this resource as a future drinking-water supply. Bedrock-well data from throughout New Hampshire were used to characterize the water quality of the bedrock aquifer. This study was part of the New Hampshire Bedrock Aquifer Assessment by the U.S. Geological Survey, in cooperation with the New Hampshire Department of Environmental Services (NHDES).

Ambient water quality of ground water in the bedrock aquifer throughout New Hampshire varies by lithochemical groups and radon-potential categories. Information on the occurrence of $\mathrm{pH}$, hardness, iron, manganese, fluoride, arsenic, and radon in bedrock ground water were compiled and statistically compared to the lithochemical and radon-potential groups from which the samples originated. A water-quality database for domestic bedrock wells was created by determining geographic coordinates for bedrock wells where waterquality samples had been collected. The database includes analyses for 1,078 wells with $\mathrm{pH}, 1,076$ wells with hardness, 1,078 with total iron, 1,076 with total manganese, 1,138 with total fluoride, 191 with total arsenic, and 221 wells with radon. For arsenic and radon, a second database of public-supply wells was examined. Constituents available for analysis were limited to those routinely collected by the NHDES Environmental Laboratory.

Nonparametric statistical analyses were used to quantify relations between concentrations of the various chemical constituents in ground-water samples and the lithochemical groups, or radon-potential categories that characterize the bedrock aquifer at the sample locations. Bedrock wells with water-quality analyses of $\mathrm{pH}$ and total hardness, iron, manganese, fluoride, and arsenic concentrations were assigned to one of the four major lithochemical groups based on the location of the well. Likewise, bedrock wells with radon data were assigned to one of the three radon-potential categories. Statistical differences among the lithochemical groups (calcareous metasedimentary, metasedimentary, mafic igneous, felsic igneous) or the radon-potential categories (high, medium, and low) were identified for all seven water-quality constituents examined. These relations were used to identify areas with relative differences in water quality as a function of the general chemical and mineralogical characteristics of the bedrock.

Most ground water from bedrock wells in New Hampshire is suitable for drinking. However, a large percentage of the water samples ( 21 percent from the domestic well data set and 12 percent from the public-supply well data set) fail to meet the U.S. Environmental Protection Agency MCL drinking-water standard of $10 \mu \mathrm{g} / \mathrm{L}$ for arsenic. Similarly, radon is a common contaminant for which a large number of samples fail to reach proposed drinking-water standards, and for fluoride,
2 percent of the water samples from the domestic well data set fail to meet the fluoride MCL drinking-water standard of $4 \mathrm{mg} / \mathrm{L}$. Iron and manganese also are common nuisance contaminants but these do not pose a threat to human health. For $\mathrm{pH}$, hardness, iron, manganese, and fluoride domestic bedrock-well samples, differences among the lithochemical groups are as follows:

1. Ground-water samples from the mafic igneous group have higher $\mathrm{pH}$ values and greater hardness than do those from either the felsic igneous group or the metasedimentary group. The mafic igneous group also had the lowest percentage of ground-water samples outside the range of USEPA SMCL drinking-water standards (from 6.5 to $8.5 \mathrm{pH}$ ). Only 4 percent of the water samples from the mafic igneous group had $\mathrm{pH}$ below 6.5, which can cause metal pipes to corrode.

2. Ground water from the bedrock aquifer in New Hampshire is typically soft to moderately hard. The percentage of the water samples with hard or very hard water is 22 percent for the calcareous metasedimentary group and 16 percent for the mafic igneous group. This result compares to less than 12 percent of the water samples from the other lithochemical groups that are hard or very hard.

3. Ground-water samples from the metasedimentary group have greater concentrations of total iron than do the felsic and mafic igneous groups. The metasedimentary group also had the highest percentage (37 percent) of ground-water samples exceeding USEPA SMCL drinking-water standard of $300 \mu \mathrm{g} / \mathrm{L}$ iron. For the other lithochemical groups, samples exceeded the standard by 22-28 percent.

4. Ground-water samples from the metasedimentary group also have greater concentrations of total manganese than do the felsic and mafic igneous groups. The metasedimentary group had the highest percentage (52 percent) of ground-water samples exceeding USEPA manganese SMCL drinking-water standard of $50 \mu \mathrm{g} / \mathrm{L}$. The calcareous metasedimentary group had the second highest percentage (40 percent) exceeding the USEPA SMCL drinking-water standard. This result compares to 32 and 34 percent for the felsic and mafic igneous groups, respectively.

5. Ground-water samples from the felsic igneous group have significantly greater concentrations of total fluoride than do those from the other groups. The felsic igneous group also had the highest percentage of ground-water samples exceeding USEPA drinking-water standards for fluoride, with 13 percent above the SMCL of $2 \mathrm{mg} / \mathrm{L}$ and 3 percent above the MCL of 4 $\mathrm{mg} / \mathrm{L}$.

The calcareous metasedimentary group was identified, utilizing the public-supply database, as having significantly higher concentrations of arsenic than the other groups. The calcareous metasedimentary group, for the domestic and the public-supply wells, had the highest percentage of groundwater samples exceeding the USEPA drinking-water MCL arsenic standard, with 27 and 21 percent, respectively, exceeding $10 \mu \mathrm{g} / \mathrm{L}$.

Radon concentrations in the air and in water from private and public-supply wells are higher at sites underlain by high 
radon-potential category rocks compared to sites underlain by rocks in the medium and low categories. Likewise, the medium radon-potential category is higher for air samples and appears to be higher for water samples than do those samples from the low category. For water samples, this difference was not identified as statistically significant, possibly because of small sample sizes in the low potential category. USEPA standards are not presently (2004) finalized for radon.
In general, samples from the bedrock aquifer tend to have higher $\mathrm{pH}$ (are less acidic), greater hardness, much higher concentrations of iron, similar concentrations of manganese, and higher concentrations of fluoride, arsenic, and radon than stratified-drift aquifers. Further investigation is needed to develop less biased water-quality databases and to develop hydrochemical analyses of the complex interrelations between water quality and the lithochemistry and ground-water-flow systems in the bedrock aquifer. 


\section{Selected References}

Alley, W.M., ed., 1993, Regional ground water quality: New York, Van Nostrand Reinhold, 634 p.

Ayotte, J.D., Montgomery, D.L., Flanagan, S.M., Robinson, K.W., and Hayes, Laura, 2002, Arsenic in ground water in eastern New England: occurrence, controls and implications for human health [abs.], in New Hampshire Consortium on Arsenic, Arsenic in New England: A multi-disciplinary scientific conference, May 29-31, 2002, Manchester, N.H.: New Hampshire Consortium on Arsenic, accessed November 6, 2003, at URL http://www.dartmouth.edu/ cehs/ ArsenicConference/abstracts $2 . \mathrm{html}$

Ayotte, J.D., Montgomery, D.L., Flanagan, S.M., Robinson, K.W., 2003, Arsenic in ground water in eastern New England: Occurrence, controls, and human health implications: Environmental Science and Technology, v. 37, no. 10, p. $2,075-2,083$.

Ayotte, J.D., Nielsen, M.G., Robinson, G.R., Jr., and Moore, R.B., 1999, Relation of arsenic, iron, and manganese in ground water to aquifer type, bedrock lithogeochemistry, and land use in the New England Coastal Basins: U.S. Geological Survey Water-Resources Investigations Report 99-4162, $30 \mathrm{p}$.

Ayotte, J.D., and Robinson, K.W., 1997, National WaterQuality Assessment Program New England Coastal Basins: U.S. Geological Survey Fact Sheet FS-060-97, 4 p.

Boudette, E.L., 1977, Two-mica granite and uranium potential in the northern Appalachian orogen of New England, in Cambell, J.A., ed., Short papers of the U.S. Geological Survey uranium-thorium symposium: U.S. Geological Survey Circular 753, p. 23-24.

Boudette, E.L., 1994, Radon in New Hampshire: New Hampshire Department of Environmental Services Environmental Fact Sheet WD-WSEB-2-3, accessed December 8, 2003, at URL http://www.des.state.nh.us/factsheets/geo/ geo-2.htm

Boudette, E.L., Canney, F.C., Cotton, J.E., Davis, R.I., Ficklin, W.H., and Motooka, J.M., 1985, High levels of arsenic in the ground waters of southeastern New Hampshire: A geochemical reconnaissance: U.S. Geological Survey OpenFile Report 85-202, 20 p.

Chormann, F.H., Jr., 1985, The occurrence of arsenic in soils and stream sediments, Town of Hudson, New Hampshire: Durham, N.H., University of New Hampshire, unpublished Masters thesis, $155 \mathrm{p}$.

Colman, J.A., Stollenwerk, K.G., and Lyford, Forest, 2002, Arsenic sources to ground water and simulations of geochemical experiments on aquifer cores at a landfill, Saco,
Maine: implications for natural remediation [abs.], in New Hampshire Consortium on Arsenic, Arsenic in New England: A multi-disciplinary scientific conference, May 29-31, 2002, Manchester, N.H.: New Hampshire Consortium on Arsenic, accessed November 6, 2003, at URL http:// www.dartmouth.edu/ cehs/ArsenicConference/abstracts2. html

D’Angelo, Diane, Norton, S.A., Loiselle, M.C., 1996, Historical uses and fate of arsenic in Maine: Orono, Maine, Water Research Institute Completion Report, University of Maine, 1986, 24 p.

Degnan, J.R., Moore, R.B., and Mack, T.J., 2001, Geophysical investigations of well fields to characterize fractured-bedrock aquifers in southern New Hampshire: U.S. Geological Survey Water-Resources Investigations Report 01-4183, $54 \mathrm{p}$.

Drever, J.I., 1988, The geochemistry of natural waters (2d ed.): New Jersey, Prentice Hall, 437 p.

Durfor, C.N., and Becker, Edith, 1964, Public water supplies of the 100 largest cities in the United States, 1962: U.S. Geological Survey Water-Supply Paper 1812, 364 p.

Flanagan, S.M., Nielsen, M.G., Robinson, K.W., and Coles, J.F., 1999, Water-quality assessment of the New England Coastal basins in Maine, Massachusetts, New Hampshire, and Rhode Island: Environmental settings and implications for water quality and aquatic biota: U.S. Geological Survey Water-Resources Investigations Report 98-4249, 62 p.

Focazio, M.F., Szabo, Z., Kraemer, T.F., Mullin, A.H., Barringer, T.H., and dePaul, V.T., 2001, Occurrence of selected radionuclides in ground water used for drinking water in the United States: A targeted reconnaissance survey, 1998: U.S. Geological Survey Water-Resources Investigations Report 00-4273, 40 p.

Focazio, M.J., Welch, A.H., Watkins, S.A., Helsel, D.R., and Horn, M.A., 1999, A retrospective analysis on the occurrence of arsenic in ground-water resources of the United States and limitations in drinking-water-supply characterizations: U.S. Geological Survey Water-Resources Investigations Report 99-4279, 21 p. Data (Tab-delimited text, $1,130 \mathrm{~Kb}$ )

Gilliom, R.J., Alley, W.M., and Gurtz, M.E., 1995, Design of the national water-quality assessment program: occurrence and distribution of water-quality conditions: U.S. Geological Survey Circular 1112, 33 p.

Hall, F.R., 1975, Chloride in natural waters of New Hampshire: New Hampshire Agricultural Experiment Station Bulletin 504, 25 p.

Hall, F.R., Donahue, P.M., and Eldridge, A.L., 1985, Radon gas in ground water of New Hampshire, in Proceedings of 
the Eastern Regional Ground Water Conference, 2d annual meeting, Portland, Maine: National Water Well Association, p. 86-101.

Helsel, D.R., and Hirsch, R.M., 1992, Statistical methods in water resources: New York, Elsevier Science Publishing Company, Inc., 522 p.

Hem, J.D., 1985, Study and interpretation of the chemical characteristics of natural water ( $3 \mathrm{~d}$ ed.): U.S. Geological Survey Water-Supply Paper 2254, 263 p.

Hitchcock, C.H., 1878, The geology of New Hampshire: Concord, N.H., Jenks, E.A., v. 3, parts 4 and 5, 386 p.

Hsieh, P.A., Shapiro, A.M.K., Barton, C.C., Haeni, F.P., Johnson, C.D., Martin, C.W., Paillet, F.L., Winter, T.C., and Wright, D.L., 1993, Methods of characterizing fluid movement and chemical transport in fractured rocks, in Chaney, J.T., and Hepburh, J.C., eds., Field trip guidebook for the northeastern United States, Boston, Mass., 1993 Geological Society of America: Amherst, University of Massachusetts, Department of Geology and Geography, contribution no. 67, p. R1-R30.

Hurlbut, C.S., Jr., 1971, Dana's manual of mineralogy (18th ed.): New York, John Wiley and Sons, Inc., 579 p.

International Agency of Research on Cancer, 1987, ARC known carcinogens arsenic and certain arsenic compounds, accessed April 14, 1998, at URL http://ntp-db.niehs.nih. gov/htdocs/ARC/ARC_KC/Arsenic_Cmpds.html

Leahy, P.P., Rosenshein, J.S., and Knopman, D.S., 1990, Implementation plan for the national water-quality assessment program: U.S. Geological Survey Open-File Report 90-174, 10 p.

Loiselle, M.C., Marvinnney, R.G., and Smith, A.E., 2002, Arsenic in ground water well in Maine [abs.], in New Hampshire Consortium on Arsenic, Arsenic in New England: A multi-disciplinary scientific conference, May 29-31, 2002, Manchester, N.H.: New Hampshire Consortium on Arsenic, accessed November 6, 2003, at URL http://www.dartmouth.edu/ cehs/ArsenicConference/ abstracts $2 . h t m l$

Lyons, J.B., Bothner, W.A., Moench, R.H., and Thompson, J.B., Jr., 1997, Bedrock geologic map of New Hampshire: U.S. Geological Survey State Geologic Map, 2 sheets, scale $1: 250,000$ and $1: 500,000$.

Mabee, S.B., 1992, Lineaments: Their value in assessing groundwater availability and quality in bedrock aquifers of glaciated metamorphic terrains-A case study: Amherst, Mass., University of Massachusetts, unpublished Ph.D. dissertation, $567 \mathrm{p}$.

Marvinney, R.G., Loiselle, M.C., Hopeck, J.T., Braley, David, and Krueger, J.A., 1994, Arsenic in Maine ground water: an example from Buxton, Maine, in Proceedings of the 1994 Focus Conference on Eastern Regional Ground Water Issues: National Ground Water Association, p. 701-715.

Medalie, Laura, and Moore, R.B., 1995, Ground-water resources in New Hampshire: Stratified-drift aquifers: U.S. Geological Survey Water-Resources Investigations Report 95-4100, $31 \mathrm{p}$.

Montgomery, D.L., Robinson, G.R., Jr., Ayotte, J.D., Flanagan, S.M., and Robinson, K.W., 2002, Digital data set of generalized lithogeochemical characteristics of nearsurface bedrock in the New England Coastal Basins: U.S. Geological Survey Fact Sheet 003-02, 4 p.

Montgomery, D.L., Ayotte, J.D., Carroll, P.R., and Hamlin, Patricia, 2003, Arsenic concentrations in private bedrock wells in southeastern New Hampshire: U.S. Geological Survey Fact Sheet 051-03, 6 p.

Moore, R.B., Boudette, E.L., and Chase, D.S., 2000, Relation of radon in ground water and air to bedrock geology of New Hampshire in Geological Society of America Northeast Section, 37th Annual Meeting, March 2002, Abstracts with Programs: v. 32, no. 1, p. A-61.

Moore, R.B., Schwarz, G.E., Clark, S.F., Jr., Walsh, G.J., and Degnan, J.R., 2002, Factors related to well yield in the fractured-bedrock aquifer of New Hampshire: U.S. Geological Survey Professional Paper 1660, 51 p., 2 pls.

Morrissey, D.J., and Regan, J.M., 1988, New Hampshire ground-water quality in National Water Summary 1986 Ground-water Quality: U.S. Geological Survey WaterSupply Paper 2325, p. 363-368.

National Academy of Sciences, 1999, Arsenic in drinking water: Washington, D.C., National Academy of Sciences Press, 273 p.

New Hampshire Department of Environmental Services, 1998, Suggested water quality testing for private wells: Environmental Fact Sheet WD-WSEB-2-3, accessed October 8, 2003, at URL http://webster.state.nh.us/des/ws2-3.htm

New Hampshire Department of Environmental Services, 2001, Fluoride in drinking water: Environmental Fact Sheet accessed November 6, 2003, at URL http://www.des.state. nh.us/factsheets/ws/ws-3-5.htm

New Hampshire Department of Environmental Services, 2002, Arsenic in drinking water: Environmental Fact Sheet accessed November 6, 2003, at URL http://www.des.state. nh.us/factsheets/ws/ws-3-2.htm

New Hampshire Department of Health and Human Services, 2004, Radon Program-frequently asked questions, accessed April 22, 2004, at URL http://www.dhhs.nh.gov/ DHHS/RADON/FAQs/default.htm\#10 
New Hampshire State Data Center, 2001, New Hampshire census information, accessed July 26, 2001 and April 11, 2002, at URL http://www.state.nh.us/osp/sdc/sdc.html

Peters, S.C., Blum, J.D., Klaue, Bjoern, and Karagas, M.R., 1998, Arsenic occurrence in New Hampshire ground water, Geological Society of America Conference, Toronto, Canada, October 1998, Abstracts with Program: abstract, no. 12653, accessed November 6, 2003, at URL http://wwwpersonal.umich.edu/ scpeters/pubs/gsa98/gsa98.html

Peters, S.C., Blum, J.D., Klaue, Bjoern, and Karagas, M.R., 1999, Arsenic occurrence in New Hampshire drinking water: Environmental Science and Technology, v. 33, no. 10. , p. 1,328-1,333.

Peters, S.C., Blum, J.D., Klaue, Bjoern, and Karagas, M.R., 2002, Arsenic processes: examples from New Hampshire [abs.], in New Hampshire Consortium on Arsenic, Arsenic in New England: A multi-disciplinary scientific conference, May 29-31, 2002, Manchester, N.H.: New Hampshire Consortium on Arsenic, accessed November 6, 2003, at URL http://www.dartmouth.edu/ cehs/ArsenicConference/ abstracts2.html

Robinson, G.R., 1997, Portraying chemical properties of bedrock for water quality and ecosystem analysis: an approach for the New England region: U.S. Geological Survey OpenFile Report 97-154, 17 p.

Robinson, G.R., Jr., Peper, J.D., Steeves, P.A., and DeSimone, L.A., 1999, Lithochemical character of near-surface bedrock in the Connecticut, Housatonic, and Thames River Basins: U.S. Geological Survey Digital Water-Resources Investigations Report 99-4000, variable scale.

Robinson, G.R., Jr., Ayotte, J.P., Montgomery, D.L., and DeSimone, L.A., 2002, Lithogeochemical character of near-surface bedrock in the New England Coastal Basins: U.S. Geological Survey Open-File Report 02-007 (digital), accessed December 8, 2003, at URL http://water.usgs.gov/ lookup/getspatial?ofr02-007_lithogeo

Robinson, G.R., Jr., and Ayotte, J.D., 2002, Spatial associations between arsenic in ground-water, sediments, bedrock, and agricultural land use in New England [abs.], in New Hampshire Consortium on Arsenic, Arsenic in New England: A multi-disciplinary scientific conference, May 29-31, 2002, Manchester, N.H.: New Hampshire Consortium on Arsenic, accessed November 6, 2003, at URL http://www. dartmouth.edu/ cehs/ArsenicConference/abstracts2.html

Rogers, R.J., 1989, Geochemical comparison of ground water in areas of New England, New York, and Pennsylvania: Ground Water, v. 27, p. 690-712.
Ryker, S.J., 2001, Mapping arsenic in groundwater-A real need, but a hard problem: Geotimes Newsmagazine of the Earth Sciences, v. 46, no. 11, p. 34-36.

SAS Institute, Inc., 1999, SAS User's Guide: Cary, N.C., version 8 .

Schumann, R.R., ed., 1993, Geologic radon potential of EPA Region 1, Connecticut, Maine, Massachusetts, New Hampshire, Rhode Island, and Vermont: U.S. Geological Survey Open-File Report 93-292a, 245 p.

U.S. Environmental Protection Agency, 1981a, Investigations of arsenic sources in ground water: Boston, Region 1, 8 p.

U.S. Environmental Protection Agency, 1981b, EPA Study confirms arsenic contamination from natural sources: Region I, EPA environment news, June-July 1981, p. 5-6.

U.S. Environmental Protection Agency, 1998a, Drinking water priority rule making: Arsenic: Office of Ground Water and Drinking Water, accessed November 9, 1998, at URL http://www.epa.gov/OGWDW/ars/ars9.html

U.S. Environmental Protection Agency, 1998b, Arsenic in drinking water-arsenic research plan: Office of Ground Water and Drinking Water, accessed September 2, 1998, at URL http://www.epa.gov/OGWDW/ars/ arsenic.html

U.S. Environmental Protection Agency, 1998c, Arsenic in drinking water-occurrence of arsenic: Office of Ground Water and Drinking Water, accessed September 2, 1998, at URL http://www.epa.gov/OGWDW/ars/ ars5.html

U.S. Environmental Protection Agency, 1999, Federal Register, Tuesday, November 2, 1999, National primary drinking water regulations; radon-222; proposed rule, accessed November 4, 2003, at URL http://www.epa.gov/safewater/ radon/radfr1.pdf

U.S. Environmental Protection Agency, 2002a, List of drinking water contaminants and MCLs: accessed November 4, 2003, at URL http://www.epa.gov/safewater/mcl.html

U.S. Environmental Protection Agency, 2002b, Secondary drinking water regulations: guidance for nuisance chemicals: accessed November 4, 2003, at URL http://www.epa. gov/safewater/consumer/2ndstandards.html

Welch, A.H., and Ayotte, J.D., 2002, National to local scale cycling of arsenic in ground water [abs.], in New Hampshire Consortium on Arsenic, Arsenic in New England: A multi-disciplinary scientific conference, May 29-31, 2002, Manchester, N.H.: New Hampshire Consortium on Arsenic, accessed November 6, 2003, at URL http://www.dartmouth. edu/ cehs/ArsenicConference/abstracts2.html 
Welch, A.H., Westjohn, D.B., Helsel, D.R., and Wanty, R.B., 2000, Arsenic in ground water of the United States-Occurrence and geochemistry: Ground Water, v. 38, no. 4, p. 589.

Wilkin, Richard; Ford, Robert; Beck, Frank; Clark, Patrick; Paul, Cynthia; LeMay, Joseph; and Puls, Robert, 2002, Arsenic geochemical behavior during ground water-surface water interactions at a contaminated site [abs.], in New Hampshire Consortium on Arsenic, Arsenic in New England: A multi-disciplinary scientific conference, May 29-31, 2002, Manchester, N.H.: New Hampshire Consortium on Arsenic, accessed November 6, 2003, at URL http://www. dartmouth.edu/ cehs/ArsenicConference/abstracts2.html

Manuscript approved for publications, June 7, 2004

Prepared by the New Hampshire-Vermont District Publications Unit- Debra H. Foster, Anita Cotton, and Ann Marie Squillacci

For more information concerning the research in this report, contact Brian Mrazik, District Chief

USGS

361 Commerce Way

Pembroke, NH 03275

Web site: http://nh.water.usgs.gov 